\title{
SANTO TOMÁS COMO EXÉGETA BÍBLICO EN SU COMENTARIO AL EVANGELIO DE SAN JUAN
}

\author{
David Torrijos-Castrillejo \\ Universidad San Dámaso \\ dtorrijos@sandamaso.es
}

\section{RESUMEN}

El artículo pretende hacer una presentación general de cómo santo Tomás procedía en la exégesis de los textos sagrados. Para ello, se concentra en uno de sus comentarios bíblicos más valorados, el del evangelio según san Juan. En la interpretación de la Escritura llevada a cabo por santo Tomás se aprecia la combinación de una gran penetración teológica con un incipiente desarrollo de algunas técnicas literarias. Destaca también la prioridad del significado literal de la Escritura, aunque esto no lleva a santo Tomás a realizar una hermenéutica meramente naturalista de ella. Es parte del sentido literal también que la Escritura sea manifestación del misterio sobrenatural de Dios. Éste es el motivo por el que Dios, el autor principal de la Escritura, ha podido pretender expresar distintas verdades con un solo pasaje.

PALABRAS CLAVE: teología escolástica, sentido literal y espiritual, teología medieval, hermenéutica bíblica, exégesis tradicional.

SAINT THOMAS AS BIBLICAL EXEGETE

IN HIS COMMENTARY ON THE GOSPEL OF SAINT JOHN

\section{ABSTRACT}

This article intends to offer a general presentation of the way in which Saint Thomas Aquinas proceeded in his exegesis of sacred texts. The author concentrates on one of Aquinas' most estimated biblical commentaries, his Lectura on the Gospel according to St. John. Aquinas combines great theological insight with an incipient development of some literary techniques. In his hermeneutics, he emphasizes the priority of the literal sense of Scripture, although this thesis does not lead him to present a purely natural interpretation. The supernatural mystery of God belongs to the literal sense of Scripture. This is why God, as the principal author of Scripture, might have intended to express different truths even within a single passage.

KEY WORDS: scholastic theology, literal and spiritual senses, medieval theology, biblical hermeneutics, traditional exegesis.

En los últimos años se ha desarrollado considerablemente el estudio de una faceta del trabajo de santo Tomás de Aquino que había quedado en un segundo 
plano en épocas precedentes: su labor como comentarista de la Escritura. A principios del siglo pasado, Chenu insistió sobre la importancia de la Escritura en el pensamiento de santo Tomás (Chenu, 1924: 199). Más recientemente, un estudioso tan autorizado como Torrell ha vuelto a hacer hincapié en que «la espiritualidad tomasiana posee una incontestable tonalidad bíblica» (Torrell, 2008: 51). En consonancia con esta intuición, el Aquinas Center for Theological Renewal de la Universidad Ave Maria (Florida) ha organizado dos simposios sobre santo Tomás como comentarista del cuarto evangelio y de la carta a los romanos respectivamente, que cuajaron en sendas publicaciones (Dauphinais-Levering, 2005 y 2012). Últimamente, en 2016, en la Universidad Nicolás Copérnico de Toruń (Polonia) ha sido erigido un centro de investigación denominado Biblical Thomism cuyo objetivo es estudiar las aportaciones de santo Tomás a los estudios bíblicos². Ya han sido organizados varios encuentros científicos de considerable envergadura, cuyas aportaciones han sido recogidas en publicaciones de gran interés (Roszak-Vijgen, 2015 y 2018). Por último, en nuestro ámbito lingüístico acabamos de dar la bienvenida al último volumen de una excelente edición bilingüe del Comentario al libro de los salmos (Casanova, 2014, 2016 y 2018). Basten estos breves apuntes para hacernos cargo del creciente interés por santo Tomás como exégeta bíblico.

En este artículo quisiera fijarme en esta faceta de santo Tomás atendiendo de manera particular a uno de sus estudios escriturísticos más relevantes, el Comentario al evangelio de san Juan. Para ello, seguiré el hilo proporcionado por el excelente estudio de Spicq (Spicq, 1946), actualizándolo con otras publicaciones posteriores y las referencias que considere importantes. Creo que el resultado es digno de interés, pese a que ya fue elaborada en español una publicación con similar metodología, también apoyada principalmente sobre esa y otras obras consultadas (Revuelta, 1971).

Spicq sostiene la siguiente tesis: todo el trabajo exegético del Aquinate se asienta sobre su labor dogmática y está motivado por el afán de conocer la verdad, más que por la crítica literaria (Spicq, 1946: 707, 710, 717-720, 736-737). Esta obra, así como otra anterior del mismo autor (Spicq, 1944) han sido tomadas como referencia para muchos autores posteriores. Sin embargo, su visión de santo Tomás ha sido también objeto de crítica, pues lo habría presentado como un gran teólogo, pero haría de él un deficiente exegeta (Centi, 1990: 10; Paretsky, 1994: 550ss.; Santi, 1994: 521ss.). Pese a esta perspectiva algo deficiente, el trabajo sigue gozando de bastante utilidad. Nos resultará útil para observar distintos aspectos de la exégesis tomasiana. Gracias a él y a otros estudios posteriores, dispondremos de una guía para indagar cómo esos rasgos se desarrollan en el Comentario al evangelio de san Juan.

${ }^{1}$ Cf. http://biblicalthomism.umk.pl (consultado 7/8/2019). 


\section{LA LECTURA SUPER IOANNEM}

Empecemos por situar el Comentario al evangelio de san Juan. En realidad se trata de una lectura, es decir, una reportatio: apuntes tomados en clase por un oyente de santo Tomás (Mandonnet, 1928: 27; Weisheipl, 1980: 3). El reportador es, según parece, Reginaldo de Piperno, quien escribió a instancias del preboste de SaintOmer, quizá Adenulfo de Anagni (Mandonnet, 1909: 167-168). A él se refieren los testimonios más antiguos, los cuales también aseguran que el Aquinate revisó la reportación, e incluso habría compuesto de su puño los cinco primeros capítulos². Aunque estos últimos datos sean menos seguros, su aparición en todos los catálogos antiguos hace que su autenticidad quede fuera de duda.

Fue escrito con seguridad en la época de la segunda enseñanza parisina, durante dos cursos académicos, entre 1270 y 1272 (Torrell, 2008: 288). Esto significa que santo Tomás ya se encontraba en una etapa de madurez intelectual (Weisheipl, 1994: 287). A esas alturas, ya había dedicado muchas clases a la exposición de la mayor parte de la Escritura y estaba involucrado plenamente en el plan de composición de la Summa Theologiae.

El Comentario se inscribe en el peculiar contexto universitario en que se desenvolvió su autor. Los maestros de Teología exponían en sus clases primero el texto sagrado y después las Sentencias de Pedro Lombardo (Weisheipl, 1994: 98). El principal oficio del maestro de Teología consistía en comentar la Escritura, auxiliado por la tradición patrística para comprender las verdades dogmáticas, arrojar luz sobre las disputas teológicas, combatir los errores heréticos... Fue precisamente en la época de santo Tomás cuando las cuestiones de Teología fueron introduciéndose cada vez con mayor extensión tanto en la vida académica cuanto en los comentarios escriturísticos. Tras la desaparición de santo Tomás, la Escritura acabó resultando casi un pretexto para las discusiones teológicas, de forma que algunos maestros

${ }^{2}$ «Item postilla super Ioannem, de qua ipse super V. Capitulo proprio stillo notavit. Totum aliud reportatio fuit, sed correctum per ipsum» (Ptolomaeus Lucensis, Historia Ecclesiastica, XXIII, 15, en Muratori, 1727: 1172E). Bernard Gui -uno de los primeros biógrafos de santo Tomás que presenta un catálogo de sus obras en aparente dependencia del de Tolomeo- también indica que escribió los primeros cinco capítulos y revisó el resto (Mandonnet, 1909: 271). Mandonnet, por su parte, considera que la labor de reportación no es una iniciativa espontánea de los alumnos, sino que se hallaba dirigida por un plan trazado por el maestro. No sería, pues, casual encontrar al hermano Reginaldo como habitual reportador, sino que, más bien, habría sido el mismo Aquinate quien valoraba su pericia (Mandonnet, 1928: 41-43). Este autor encarece la fidelidad del reportador hasta el punto de afirmar que se puede considerar como una reproducción literal (Mandonnet, 1909: 167); debido a esa misma confianza en Reginaldo, considera espúreo el dato que aporta Tolomeo acerca de la autoridad de los primeros capítulos, ya que este reportador, que en otras ocasiones sí lo menciona, aquí no lo hace (Mandonnet, 1928: 151). Por otro lado, está la opinión de Torrell, para quien es improbable no sólo que Tomás escribiera de su mano los primeros capítulos sino incluso que revisara el resto (Torrell, 2008: 290). 
se especializaron en la lectura continua de la Escritura, disciplina que acabaría quedando relegada a un papel subalterno dentro de la Teología. Sin embargo, aunque en la obra del Aquinate estén diferenciados con claridad sus escritos de tipo escolástico y los de tipo estrictamente escriturístico, no podemos decir que en su pensamiento se haya dado una disociación de estas dimensiones, sino más bien, al contrario, su Teología sigue bebiendo de la Escritura como de una fuente (Chenu, 1924: 199ss.; Mandonnet, 1929: 507; Chenu, 1962: 20-24; Ménard, 1964: 117; Philippe, 1998: 10-11).

Para comprender mejor el lugar que ocupa este escrito en la obra de santo Tomás, hay que acudir a la presentación que él mismo hace de él. Según nos dice en el proemio con que abre el Comentario, mientras que los otros evangelistas se habrían ocupado de la humanidad de Jesucristo, el propósito de Juan sería darnos a conocer su divinidad ${ }^{3}$. En ese sentido, parece justo decir que el tema del Comentario de san Juan es el Verbo, en cuanto se trata de la persona divina con quien está unido hipostáticamente el hombre Jesús ${ }^{4}$. La mencionada intención del evangelista lleva a santo Tomás a preguntarse de qué manera se puede tener acceso al conocimiento de Dios. La respuesta es patente: otros han tratado de acceder al conocimiento de Dios de diferentes maneras, pero ahora Juan lo ha visto en una altísima contemplación y nos hace partícipes de ella (Super Io., Pr., \$\$2-8).

De este modo, descubrimos en el Comentario diferentes referencias que entroncan su contenido con la propia vida del Aquinate. En primer lugar, la persona de Juan, parece estar caracterizada como si fuera la de un maestro de la Orden de Predicadores, distinguido por el estado de virginidad (Super Io., Pr. \$11; 2, lect. 2, $\$ 370$ ) y por su "perspicacia de entendimiento"s, las cuales le permiten instruirnos no sólo respecto de la vida activa sino incluso de la contemplativa -una combinación de las dos facetas de la vida religiosa muy propia de los dominicos- $-^{6}$. Asimismo, destaca de él su intimidad con Cristo (Super Io., Pr., \$\$10-11; 18, lect. 3, \$2305),

${ }^{3}$ Cf. Super Io., Pr., $\$ \$ 10-11 ; 6$, lect.1, $\$ 844$. A falta de la edición crítica, citaré el texto en la edición Marietti, como suele ser habitual. El resto de las citas de santo Tomás las tomo de www.corpusthomisticum.org. "[Ioannes] dignius Evangelium suum incepit, quam alii. Ipsi enim annuntiaverunt Christum Filium Dei ex tempore natum [...]. Ioannes vero dicit eum ab aeterno fuisse [...] ipsum esse Deum [...] eum apud Patrem semper fuisse» (ibíd., 1, lect. 1, \$66). La intención de Juan de poner de relieve la divinidad explicaría por qué sólo él introduce la expresión amen, amen (ibíd., 3, lect. 1, \$430) e incluso por qué se muestra la debilidad de la carne (ibíd., 11, lect. 6, \$1541). lect. 3, \$98).

${ }^{4}$ «[Ioannes] Intendebat in isto Evangelio tradere nobis cognitionem de Verbo» (Super Io., 1,

${ }^{5}$ «Intellectus eius perspicacitatem» (Super Io., 21, lect. 5, \$2639; cf. ibíd., \$2641); «Ioannes perspicax in cognoscendo» (ibíd., 21, lect. 2, \$2592); «Ioannes altior intellectu» (ibíd., \$2594).

${ }^{6}$ Cf. Super Io., Pr., $\$ 1$; véase también Catena in $M t$, I, lect. 1; Catena in $M c$, I, lect. 7. Sobre este rasgo de la Orden de Predicadores leamos, por ejemplo: «Sicut enim maius est illuminare quam lucere solum, ita maius est contemplata aliis tradere quam solum contemplari» $(S$. Th. II-II, 188, 6). En el mismo Comentario: «Ex abundantia enim caritatis est quod aliqui diligentes interdum quietem propriae contemplationis intermittant, ut procurent proximorum utilitatem» (Super Io., 21, lect. 3, \$2618; Bonino, 2005: 318-346). 
que es la condición para comunicar su especial conocimiento7. Esta concepción del evangelista enlaza también con el ambiente académico en que fue compuesto el Comentario y que lleva a comprender al Verbo encarnado como Maestro de la ciencia sagrada, es decir, la Teología (Bonino, 2005: 329).

\section{EL TEXTO BÍBLICO}

¿Qué texto de la Escritura usó santo Tomás? Parece seguro que no conocía personalmente la lengua griega ni la hebrea ${ }^{8}$. Utilizaba tan sólo para su investigación el texto que había recibido de la Biblia Vulgata latina. Se consideraba autorizado el texto de la versión llamada Biblia universitaria, conocida como Ejemplar parisino de la Biblia o sencillamente Biblia de París, que era fruto de una revisión del siglo XII sobre el texto fijado en tiempos de Alcuino. No se trataba de un texto con un gran rigor crítico, pero se presume que utilizaba las correcciones de Hugo de santo Caro, aunque no diga de dónde toma las variantes. Estas correcciones se beneficiaban de las mejoras que introdujo el canciller de la Universidad, Esteban Langton, que es también quien determinó la disposición de los libros en la edición de la Biblia. Langton introdujo una división en capítulos más homogénea que la propuesta por Alcuino, aunque no se empiezan a citar los textos con el capítulo correspondiente hasta finales del siglo XII. Estas modificaciones se verán reflejadas en la Biblia de los dominicos de París, editada por los padres del convento de Santiago y que además tiene una división de cada capítulo en siete partes, según las primeras letras del alfabeto, a la usanza de la literatura pagana, que introdujo Tomás Gallo. Esta Biblia será la que utilice el Aquinate al comentar la Escritura (Spicq, 1946: 695-697; Santi, 1994: 512-521).

\section{EL CANON BÍBLICO}

Probablemente fue en 1256 cuando santo Tomás pronunció en París una lección inaugural en que explicó el orden de los libros canónicos de la Escritura?.

${ }^{7}$ En particular es interesante la explicación que da de la predilección de Juan cuando dice que se debe a la perspicacia de su intelecto, a la virginidad de su condición y a su juventud (Super Io., 21, lect. 5, \$2639), tres características que son también aplicables al mismo santo Tomás: «Ce que Thomas dit de Jean, ne pourrions-nous pas le dire aussi de Thomas commentant l'évangile de Jean [...]?» (Philippe, 1998: 11).

${ }^{8}$ Pese a su desconocimiento del griego, conoce la existencia de varias célebres versiones griegas de la Escritura: la Septuaginta, la de Áquila, Símaco y Teodoción, a través de las noticias que aportan Jerónimo, el Crisóstomo y los correctores. La versión del salterio que utiliza es la galicana. Además, se puede apreciar en él un interés crítico acerca de las traducciones: cf. Super Psalmos, Pr.

${ }^{9}$ Me refiero al conocido como segundo sermón aquinatense, Hic est liber mandatorum Dei (Torrell, 2008: 78; Weisheipl, 1994: 134-135). Voy a ir glosando este escrito en las siguientes líneas. 
En ese texto manifiesta su comprensión de la Escritura como si fuera «un solo documento homogéneo y comprensible teológicamente» (Santi, 1994: 526). Dice que la utilidad de la Escritura es máxima porque permite al hombre alcanzar una vida plena, en virtud de la gracia, de la justicia y, en fin, de la gloria. A esta vida la llama "sagrada» y dice que se puede llevar a cabo gracias a dos instancias que Dios ha introducido en el mundo: los preceptos y la gracia. Mientras que al Antiguo Testamento le es propio principalmente el mandato (véase también Super Io., 10, lect. 6, $\$ 1458$; 15 , lect. 5, \$2057), a la Nueva Alianza le compete precisamente la gracia que el Legislador ha concedido. De esta razón teológica obtiene la división de toda la Escritura en ambas partes, que no se excluyen entre sí.

El Antiguo testamento se divide según la forma de comunicar los mandatos, es decir, según si se trata de coacción o de invitación. La primera forma es propia de la potestad regia, la cual hace capaz de castigar el mal y de instituir mensajeros; la segunda forma, en cambio, es más bien una instrucción paternal. Resultan así tres mandatos en la Escritura: los del rey, los de los mensajeros y los paternales. De esta suerte, asume la división en tres partes del Antiguo Testamento, la cual procede del judaísmo antiguo ${ }^{10}$ : la Ley, mandada por el rey; los profetas, a quienes llama «heraldos de Dios que hablaban al Pueblo de parte de Dios mismo y que inducían al cumplimiento de la Ley»" ; y los hagiógrafos, «quienes, si bien inspirados por el Espíritu santo, no hablaron de parte de Dios sino de parte suya $»^{12}$. Además, señala que Jerónimo pone a los apócrifos aparte, pero que, sin embargo, la Iglesia recibió algunos de los que éste llama así, aunque se dude de la autenticidad literia, porque la inspiración resulta cierta ${ }^{13}$.

En la misma lección a la que nos estamos refiriendo, lleva a cabo la división del Nuevo Testamento en función de tres consideraciones acerca de la gracia:

${ }^{10}$ La recepción de esta tradición en santo Tomás -a tenor de lo que él mismo declaradepende de san Jerónimo (Praefatio in libros Samuel et Malachim, PL 28, 547-558). En el Comentario de san Juan señala esta división como una de las posibles de acuerdo a la Escritura misma: cf. Super Io., 10, lect. 6, $\$ 1458$.

${ }^{11}$ «Fuerunt quasi nuntii et praecones Dei ex persona Dei populo loquentes et ad observantia legis inducentes».

${ }^{12}$ «Qui Spiritu sancto inspirati locuti sunt non tamen ex parte Domini, sed quasi ex se ipsis». Dentro de éstos se sitúan los libros de Salomón, que son auténticamente suyos, según su opinión. Adopta para ellos la distribución plotiniana a través de Macrobio, quien los ordena según los grados de virtud: cf. S. Th. I, 61, 5 .

${ }^{13}$ En esta opinión jeronimiana están de acuerdo algunos de los maestros cercanos a santo Tomás, como Hugo de san Víctor (De Scripturis et scriptoribus sacris praenotatiunculae, 6, PL 175, 15), el autor de Ysagoge in Theologiam (PL 167, 318) y Felipe de Harveng (De damnatione Salomonis, PL 203, 629C-D, 659A-B). Santo Tomás por el contrario, adopta la postura de Hugo de santo Caro, el cual considera que se puede distinguir entre la autenticidad literaria y la veracidad de la obra: «[...] ex auctoritate auctorum robur non habent, sed magis ex Ecclesiae receptione» (Spicq, 1946: 698), cosa que aplica, por ejemplo, al Eclesiástico en S. Th. I, 89, 8, ad 2 (Synave, 1924: 526), aunque introduce como novedad la referencia a la autorización eclesiástica: cf. Super Io., 21, lect. 6, \$2656 (Santi, 1994: 527-530). 
los Evangelios, donde se habla del origen de la gracia, las epístolas paulinas, que tratan sobre el poder de la gracia, y el resto de los libros del Nuevo Testamento, los cuales versan acerca de la ejecución del poder de la gracia. Los Evangelios sinópticos nos dan noticia de la humanidad de Cristo, según su condición regia (Mateo), profética (Marcos) o sacerdotal (Lucas). Por el contrario, Juan se ocupa de la divinidad. También hace una consideración inspirada en la aplicación tradicional del tetramorfos: Mateo, bajo figura de hombre, se centra sobre todo en la Encarnación; Marcos, representado como león (Ap 5,5), subraya la victoria de la Resurrección; Lucas, cuya figura es el buey, víctima para el sacrificio, destaca el misterio de la Pasión; Juan es el águila que vuela hasta la altura de la divinidad (véase también Super Io., Pr., $\$ 11$ ). El orden canónico de los libros está relacionado con su contenido, puesto que el Antiguo Testamento comenzaba con el principio de la creación a partir de la naturaleza incorruptible de Dios, del mismo modo como el Nuevo concluye con la consumación de la criatura por la naturaleza incorruptible de Cristo (compárese con Super Io., Pr. Hier., \$19). Hasta aquí se extiende cuanto expone en dicha lección inaugural.

Aunque fueran bien conocidos en la Edad Media, santo Tomás no suele citar los libros apócrifos. Sin embargo, en el Comentario de san Juan aparecen algunas referencias a la obra De infantia salvatoris (Super Io., 1, lect. 14, \$264; 2, lect. 1, $\$ 364)$, cuya veracidad resulta impugnada, así como al Itinerarium Clementis, al cual atribuye empero cierta autoridad (Super Io., 1, lect. 15, \$300; 13, lect. 2, \$1761; Super Rom., Pr.). También conoce las leyendas acerca de la vida de san Juan (Super Io., 21 , lect. 5, \$2649).

\section{LA FILOLOGÍA BÍBLICA}

La mencionada ignorancia del Aquinate acerca de las lenguas hebrea y griega no se debe a que ese conocimiento no fuera asequible en su época (Fernández, 1909: 231-232), puesto que el estudio estaba bastante extendido. Efectivamente, consta que Roger Bacon había compuesto una gramática griega y también que era posible aprender la lengua, como lo prueba el hecho de que un hermano en religión de santo Tomás, muy cercano a él, Guillermo de Moerbeke, no sólo la dominaba sino que sus traducciones de Aristóteles al latín eran de gran calidad. Es también sabido que la lengua griega se enseñaba tanto en Nápoles como en Montecassino, lugares ambos donde santo Tomás se formó. Así, pues, si ignoraba el griego sería más bien porque consideró que no disponía del tiempo suficiente para adquirir estos conocimientos (Gardeil, 1903: 431).

Resulta más difícil comprender cómo pudo no estudiar hebreo, puesto que se estudiaba bastante por entonces: de acuerdo con las noticias de algunos testigos, llegó incluso a formar parte, junto con el griego, de la enseñanza eclesiástica oficial. También Roger Bacon había publicado una gramática para aprendices de esta lengua. Sin embargo, hay que señalar que sólo estudiaban el hebreo los que se veían obligados a la polémica con los judíos, más que los exégetas y los teólogos. 
No obstante, su preocupación por la lectura literal de los textos, sobre la cual se funda cualquier otra lectura ( $S$. Th. I, 1, 10, in c.), le motivó tanto al uso de los glosarios, las concordancias y las etimologías de que disponían los teólogos, como a investigar algunos elementos de las lenguas bíblicas que le permitieran la comprensión del texto en su integridad ${ }^{14}$.

Parece conocer por lo menos el alfabeto hebreo en su pronunciación sefardí (Super Psalmos, 2, lect. 1; In Threnos, Pr.). También tenía noticia de las metátesis que suelen producirse en las lenguas semíticas y sabe que en hebreo las vocales son accidentales respecto a las consonantes (Super Io., 3, lect. 4, \$502). Algo conoce de la conjugación de los verbos hebreos (Super Io., 17, lect. 2, \$2203) y tampoco ignora ciertos matices de las preposiciones (Super Io., 12, lect. 7, \$1691).

Tuvo interés por informarse acerca del griego, debido también al comentario de Aristóteles y del Pseudo-Dionisio, aunque no menos por el empleo de esta lengua por la Escritura y otros padres. Se da cuenta de algunas diferencias entre el griego y el latín, como el empleo del artículo $^{15}$; aprecia la importancia que tienen las traducciones para la hermenéutica del texto, pues pueden llegar a poner en peligro la fe ${ }^{16}$; insiste en la diversidad de la declinación de los sustantivos, que puede también influir en la hermenéutica (Super Io., 8, lect. 3, \$1183): así, en griego cabe emplear el genitivo en lugar del ablativo (Super Rom., 2, lect. 3; Gardeil, 1903: 432). También expone numerosas etimologías griegas, algunas de ellas contenidas en la obra

${ }^{14}$ Respecto de las etimologías hebreas, aparecen muchas de ellas en el Comentario de san Juan, aunque no suelen ser demasiado acertadas. Veamos algunos ejemplos. Super Io., 1, lect. 15, \$305: Iona; ibíd., lect. 16, \$318: Nazareth (ibíd., 19, lect. 4, \$2420: Nazarenus); ibíd., 1, lect. 16, \$322: Israel (ahí explica también que esta etimología procede de la Glosa, Is. 44, 2, PL 113, 1286D-1287A, la cual, por su parte, depende de Isidoro de Sevilla, Etymologiae, 7, 7, PL 82, 282A); Super Io., 2, lect. 2, \$368: Capharnaum; ibíd., 12, lect. 3, \$1621: Hosanna (recibe esta etimología de Agustín, In Io., 51, 2, PL 35, 1764); Super Io., 18, lect. 2, \$2290: Malchus, ibíd., 19, lect. 3, \$2403: Lithostratos, Gabbatha; ibíd., 19, lect. 4, \$2420: Iesus; ibíd., 20, lect. 5, \$2546: Thomas. A veces las estimologías son también variables: cf. Super Io., 1, lect. 16, $\$ 314$ y 5, lect. 1, $\$ 702$ : Bethsaida. En ocasiones, traduce de modo hebreo nombres griegos: cf. Super Io., 12, lect. 4, \$1633: Philippum; véase Super Is., 8, lect. 4. También traduce nombres griegos como si fueran hebreos: cf. Super Io., 13, lect. 1, \$1728: Pascha; ibíd., 18, lect. 1, $\$ 2274$ : Cedron. Sin embargo, muchos de estos errores los debe a otros autores más osados que él respecto a las etimologías, herederos de Jerónimo, así como de la usanza rabínica.

${ }^{15}$ "Graeci, quando volunt significare aliquid segregatum et elevatum ab omnibus aliis, consueverunt apponere articulum nomini, per quod illud significatur [...] ideo Evangelista volens significare segregationem et elevationem istius Verbi super omnia, apposuit articulum ad hoc nomen logos, ut si dicatur in Latino, ly verbum» (Super Io., 1, lect. 1, \$33; cf. ibíd., 1, lect. 4, \$123; 1, lect. 12, \$233; $S$. Th. II-II, 1, 6, in c.). El Aquinate reconoce que esta investigación no es baladí, sino que puede significar un verdadero argumento teológico fundado sobre la literalidad del texto; de hecho, Orígenes (In Io., 2, 2, PG 14, 108B-113D) se habría servido de ello para argumentar de modo contrario a la plena consustancialidad del Padre y el Hijo: cf. Super Io., 1, lect. 1, $\$ 58$.

${ }^{16}$ Cf. Super Io., 3, lect. 1, $\$ 435$. Sobre el problema de la traducción del griego al latín trata en su opúsculo Contra errores Graecorum, I, Pr: «[...] multa quae bene sonant in lingua Graeca, in Latina fortassis bene non sonant, propter quod eandem fidei veritatem aliis verbis Latini confitentur et Graeci». 
en que nos estamos centrando de modo particular ${ }^{17}$. Según santo Tomás, en ocasiones, por razones de fondo en la traducción, la gramática debe ser puesta al servicio de las exigencias del mensaje de la Escritura ${ }^{18}$. Por tal motivo, comentando el prólogo de Juan, señala que «el traductor no se cuidó de conservar la regla de la gramática para así enseñar perfectamente la verdad» ${ }^{19}$.

Es tan importante para él la lectura literal de la Escritura que interpreta cada término de la versión Vulgata como si gozara de inspiración verbal: desde el tiempo de los verbos ${ }^{20}$ hasta las preposiciones ${ }^{21}$, los pronombres (nihil: Super Io., 1, lect. 2, \$\$79-83), los adverbios (sicut: ibíd., 15, lect. 2, \$1999; 17, lect. 5, \$2240) y las conjunciones ${ }^{22}$. Sin embargo, no se preocupa tanto por la sintaxis ${ }^{23}$.

\section{LA CRÍTICA TEXTUAL}

La versión de la Biblia que usaba el doctor Angélico estaba autorizada por dos sentencias atribuídas a san Jerónimo ${ }^{24}$. La primera de ellas era, en realidad, de san Agustín y negaba la posibilidad de que los hagiógrafos errasen al escribir los libros canónicos ${ }^{25}$ : es tal la seguridad que podemos tener en esas obras que, en caso de hallar

${ }^{17}$ Cf. Super II Cor., 5, lect. 3 (cf. In Tit., 2, lect. 3): sobrietas; Super Io., 2, lect. 1, \$360: architriclinus; ibíd., 3, lect. 1, \$425: Nicodemus; ibíd., 18, lect. 1, \$2274: Cedron; ibíd., 20, lect. 5, \$2546: Didymus, etc.

${ }_{18}^{18}$ Et licet murmur sit generis neutri, tamen Hiernymus ponit in masculino, quia hoc habebat antiqua grammatica, vel ut ostendat divinam Scripturam non subiacere regulis Prisciani» (Super Io., 7, lect. 2, \$1030).

19 "Et licet hoc nomen "sanguis" in Latino non habeat plurale, quia tamen in Graeco habet, ideo translator regulam grammaticae servare non curavit, ut veritatem perfecte doceret» (Super Io., 1, lect. $6, \$ 160)$.

${ }^{20}$ Cf. Super Io., 1, lect. 1, \$39; cf. ibíd., 13, lect. 3, \$1773; 17, lect. 1, \$2190; lect. 6, \$2257.

${ }^{21}$ Éste es uno de los temas en los que insiste al comentar el prólogo de san Juan: cf. Super Io., 1, lect. 1, \$45: apud, in; ibíd., \$46: apud; ibíd., lect. 2, \$\$75-77: per (cf. Super I Tim., 2, lect. 3); Super Io., 1, lect. 6, \$162: de, a, ex, ibíd., lect. 10, \$202: de.

${ }^{22}$ Cf. Super Io., 9, lect. 1, \$1301 (cf. ibíd., 12, lect. 7, \$1701): ut (cf. ibíd., \$1691); ibíd., 16, lect. 1, \$2073: sed.

${ }^{23}$ Sin embargo señala algún anacoluto, como el de Rm 16,23: cf. Super Rom., 16, lect. 2; Super Io., 16, lect. 5, \$2120; Super II Tim., 2, lect. 4.

${ }^{24}$ Voy a concentrarme en la primera. La segunda se utilizaba para justificar la legitimidad de la investigación crítica: «Ut enim veterum librorum fides de Hebraeis voluminibus examinanda est; ita novorum Graecae sermonis normam desiderat» (Hieronymus, Epistola, 71, 5, PL 22, 671-672; cf. Gratianus, Concordia, 1, d. 9, 6, PL 187, 50B).

${ }^{25}$ Cf. Augustinus, Epistola, 87, 3, PL 33, 277. Véase Gratianus, Concordia, 1, d. 9, 6, PL 187, 49D-50A. Esta enseñanza de san Agustín la hace suya el Aquinate explícitamente: «[...] "noli verbis contendere" [ $2 \mathrm{Tm}$ 2,14]. Pugnae legis sunt, quae non ex vitio disputantium, sed quae oriuntur ex contrarietate in Scriptura, vel rationibus contrariis. Sed numquid huiusmodi semper sunt vitandae? Dicendum est: in Scriptura sacra, secundum veritatem, nihil est contrarium [cf. Quodlibet IV, q. 2, 
algo aparentemente contradictorio con lo que tenemos por verdad, resulta preferible aceptar nuestra propia confusión antes de admitir que haya podido equivocarse el autor inspirado. No obstante, también se admite que podría darse la falsedad en el manuscrito o bien el traductor podría haber incurrido en un error. Sin embargo, aun concediendo estas posibilidades, santo Tomás no se distingue por una exhaustiva crítica textual, pese a seguir ciertos principios metodológicos para ella ${ }^{26}$.

Encontramos en los textos de santo Tomás algunas noticias conocidas en su época sobre el texto, a la vez que señala en ocasiones algunas variantes de lectura ${ }^{27}$, sin darles siempre demasiada importancia, puesto que generalmente tampoco cambian el sentido ${ }^{28}$. Sin embargo, suele tener mejor intuición incluso que otros exégetas de su tiempo: así, por ejemplo, de acuerdo con lo que ha mostrado la arqueología actual (Freund, 2014: 28), se da cuenta de la necesidad de suponer que existan dos Betanias (Super Io., 1, lect. 13, \$251), apartándose de la opinión de Orígenes y de san Juan Crisóstomo.

Trata de verificar las citas del Antiguo Testamento que aparecen en el Nuevo, notando que éste recoge los pasajes de aquél según la traducción de la Septuaginta $a^{29}$. También procura cuidar el modo exacto de $\operatorname{leer}^{30} \mathrm{y}$ puntuar los textos ${ }^{31}$, aunque

a. 2, in c.; Augustinus, De Genesi ad litteram, 2, 5, 9, PL 304, 267]. Sed si aliquid apparet contrarium, vel est, quia non intelligitur, vel quia corrupta sunt vitio scriptorum, quod patet specialiter in numeris et genealogiis. Et ideo haec, quia determinari non possunt, vult quod vitentur. Et hoc ideo, quia inutiles sunt. Et doctor ad duo intendere debet, scilicet ad utilitatem, et ad veritatem: "veritatem meditabitur guttur meum", et cetera [Pr 8,7]. "Ego Dominus Deus tuus docens te utilia" [Is 48,17]. Non est ergo intromittendum se de inutilibus, et quae non habent solidam veritatem. Scire enim singularia, ut sunt genealogiae, non est ad perfectionem intellectus, nec ad instructionem morum, nec fidei. Et sunt vanae, quia non habent solidam veritatem» (Super Tit., 3, lect. 2).

${ }^{26}$ Spicq los resume de esta manera: «1. Une leçon qui est en contradiction avec d'autres textes certains de l'Écriture doit être fausse; 2. L'unanimité des témoinages manuscrits l'emporte sur la clarté du sens; 3. L'usage de l'Écriture prévaut sur une correction facilitante; 4. L'intérêt d'une restitution est fonction de ses conséquences théologiques; 5 . Dans le choix des variantes, on tiendra compte du nombre des témoins et, en premier lieu, de l'autorité de la version latine, puis des anciens qui reproduisent telle leçon. En ce domaine, saint Jérome pour les latins, saint Jean Chrysostome pour les grecs ont plus de poids que d'autres, alors qu'Origène est souvent suspect, car sa doctrine n'est pas sûre; 6 . Les corruptions viennent des scribes et sont spécialement fréquentes dans les chiffres et les noms propres" (Spicq, 1946: 710).

${ }^{27}$ Cf. Super Io., 1, lect. 8, \$184; 5, lect. 4, \$777; 6, lect. 7, \$966; lect. 9, \$995; 7, lect. 1, $\$ 1012$; 8, lect. 4, \$1217; lect. 8, \$1274; 14, lect. 5, \$1925; 16, lect. 6, \$2134; 10, lect. 5, \$2462; 20, lect. 1, \$2476; Super Rom., 5, lect. 5; Super I Tim., 4, lect. 3.

${ }^{28}$ Cf. Super Io., 21, lect. 5, \$2646; Super Rom., 4, lect. 3.

${ }^{29}$ Cf. Super Io., 2, lect. 2, \$389 (Is 1,16); ibíd., 12, lect. 7, \$1699 (Is 6,10); Super Rom., 1, lect. 6 (Ha 2,4); ibíd., 9, lect. 3 (Ex 9,16), etc.

${ }^{30}$ Por ejemplo, resulta interesante cómo analiza las diversas lecturas de los padres en Jn 1,3.4: su versión (sine ipso factum est nibil. Quod factum est in ipso vita erat) coincide con la de la homilía Vox spiritualis aquilae (Super Io., 1, lect. 2, \$90). Esto no es de extrañar, puesto que, en realidad, dicha obra no pertenece a Orígenes, como se decía en tiempos de santo Tomás, sino a Escoto Eriúgena 
de ordinario no busque el origen de las variantes que apunta; le bastan las referencias que dan los padres sin preocuparse por los manuscritos mismos. Como asienta toda su exégesis en la autoridad de la Escritura, su investigación crítica pretende fundamentalmente elucidar el pensamiento contenido en el texto ${ }^{32}$.

\section{CARACTERÍSTICAS GENERALES DE LA EXÉGESIS DE SANTO TOMÁS}

\section{1. EXÉGESIS LITERAL Y ALEGÓRICA}

La Summa Theologiae comienza con una cuestión introductoria donde se enuncian ciertos criterios metodológicos para la ciencia sagrada, es decir, aquella a la que se tiene acceso mediante la revelación. En el décimo artículo se pregunta cómo se puede afirmar que tras la letra de la Escritura se hallen los distintos sentidos tradicionales. Asevera decididamente que el sentido literal es el fundamental, aquel sobre el que se debe erigir toda hermenéutica bíblica, puesto que ése es el sentido inmediato que el autor quiso dar. Éste es el espíritu en que se componen los comentarios de la Escritura de santo Tomás: los padres de la Iglesia ya han manifestado suficientemente el sentido alegórico de los textos, ahora queda elucidar el sentido literal (Super Iob, Pr.). Por ello en el Comentario de san Juan tratará de exponer precisamente este sentido (Spicq, 1946: 712). Sin embargo, santo Tomás no se opone diametralmente a la exégesis de su tiempo -que hacía uso de los padres con el solo propósito de proporcionar una exposición edificante del texto-, puesto que de hecho elabora una Catena de los cuatro evangelios. Pero es claro que, para él, se trata ante todo de desentrañar el mensaje profundo contenido en la letra, sin dejarse llevar por el deseo de embellecer el comentario bíblico (Roszak, 2019: 8).

(PL 122, 288A-B) y sabemos que la Vulgata usada por Tomás fue fijada en buena medida en época carolingia. Compara esta lectura con la de Agustín (quod factum est, in ipso vita erat. Super Io., 1, lect. 2, \$91; cf. Augustinus, In Io., 1, 16, PL 35, 1387), la de Hilario (et sine ipso factum est nihil, quod factum est in ipso. Vita erat. Super Io., 1, lect. 2, \$93; cf. Hilarius, De Trin., 1, 10, PL 10, 31C; 2, 19, PL 10, 63A), la del Crisóstomo (et sine ipso factum est nibil quod factum est. In ipso vita erat. Super Io., 1, lect. 2, $\$ 94$; cf. Ioannes Chrisostomus, Homilia in Io., 5, 2, PG 59, 57) y la del verdadero Orígenes (quod factum est in ipso, vita erat: Super Io., 1, lect. 2, \$92; Origenes, In Io., 2, 10, PG 14, 142C-D). A Spicq le parece que la explicación del predominio de la lectura del Crisóstomo entre los códices griegos que da el Aquinate (Super Io., 1, lect. 2, \$94) hace pensar que se inclina personalmente por esta interpretación (Spicq, 1946: 710).

${ }^{31}$ Cf. Super Io., 7, lect. 5, \$1089; 14, lect. 8, \$\$1976-1977. Vemos también que se da cuenta santo Tomás de la unidad que encierra en sí la perícopa de Jn 10,19-30 (cf. Super Io., 10, lect. 5, \$\$14271451 ; véase, en especial, $\$ 1427$ y $\$ 1432$ ), así como de la novedad del contenido de Jn 10ss., respecto a los capítulos precedentes (cf. ibíd., 2, lect. 1, \$335).

${ }^{32}$ Cf. Super Io., 16, lect. 6, \$2136; 18, lect. 5, \$2330. 
El significado literal es el intentado por el autor de la Escritura, pero, ¿quién es ese autor? Para santo Tomás, la autoridad humana del texto bíblico no puede llevar a olvidarnos de la divina. De ahí que es considerado tan literal el sentido que buscaba el hagiógrafo, cuanto el perseguido por Dios mismo (Manresa Lamarca, 2017). Por eso, aunque llame al sentido literal «sentido histórico», no pretende hacer una lectura del texto desnuda de la fe, pues el sentido literal constituye la «verdad de la fe» ${ }^{33}$.

¿Puede haber distintos sentidos literales en un texto? Téngase en cuenta, en primer lugar, que tras una sola expresión verbal es posible descubrir distintas realidades significadas sin apartarse de la letra. En segundo lugar, santo Tomás se apoya sobre todo en la omnisciencia divina a la hora de admitir varios sentidos literales bajo el mismo texto, es decir, sentidos positivamente intentados por los autores: «El sentido literal es el buscado por el autor: el autor de la sagrada Escritura es Dios, que, con su entendimiento, abarca todas las cosas a la vez: por tanto, nada impide -como dice san Agustín en las Confesiones- que haya diversos sentidos en un texto de la Escritura, incluso de acuerdo con el sentido literal $»^{34}$. Vemos que afirma expresamente que la pluralidad de lecturas pueden ser "etiam secundum litteralem sensum», es decir, no meras interpretaciones espirituales, como algunos han entendido (Zarb, 1930: 344-350; Salguero, 1978: 31). De manera similar, Synave había afirmado que santo Tomás no admite sino un solo sentido literal (Synave, 1926: 40-65). Este último autor apeló a otros pasajes en los que el Aquinate declara que señalar un sentido único para cada término ayuda a hacer comprensible el texto. Por último, pese a conceder la variedad de tales sentidos literales, Spicq opinaba que, de hecho, el Aquinate trata de acogerse sólo a uno cada vez y por eso manifiesta en cada caso cuál es la interpretación que le parece mejor. En resolución, cabría afirmar que, «en la práctica, el Doctor angélico no ha afrontado nunca una multiplicidad de sentidos literales» (Spicq, 1946: 713).

Un intento de tomar partido en esta disputa sobre cómo entender a santo Tomás ha sido situar el texto arriba citado dentro del contexto de la explicación de los sentidos literales, sin por eso rechazar la opinión de Synave, el cual consideraba que ahí el término litteralis se debía entender en sentido lato (Perrella, 1945: 289-292; Benoit, 1978: 19-30). No obstante, resulta también difícil admitir esta hermenéutica de las palabras de Tomás, como ya había sido expresado con anterioridad (Ceuppens, 1930: 167-169). Por su parte, Boyle -en una feliz resonancia de las palabras de Spicq- ha afirmado que, «en la práctica», santo Tomás sí admite

\footnotetext{
${ }^{33}$ «Secundum quod accipitur ipsa veritas fidei, est sensus historicus» (Super Sent., Pr., a. 5, in c.). «Sola canonica scriptura est regula fidei» (Super Io., 21, lect. 6, \$2656).

${ }^{34}$ «Sensus litteralis est quem auctor intendit: auctor autem sacrae Scripturae Deus est, qui omnia simul suo intellectu comprehendit: non est incoveniens, ut dicit Augustinus XII Confessionum [31, 42, PL 32, 844], si etiam secundum litteralem sensum in una littera Scripturae plures sint sensus» (S. Th. I, 1, 10, in c.).
} 
varios sentidos e incluso exige no insistir demasiado en la interpretación a la cual uno da prioridad, pues también otras puedes ser «verdaderas» ${ }^{35}$. En efecto, basta leer algunas de sus indicaciones exegéticas para encontrarse afirmaciones como ésta: «[...] las palabras de los profetas se referían al momento entonces presente de tal manera que también se referían a él como figura del futuro ${ }^{36}$. Es decir, las palabras del profeta, aunque estuviesen refiriéndose a un acontecimiento de su propia época, no por ello dejaban de anunciar, a la vez, el momento futuro en que vendría Cristo.

Sobre la problemática de la pluralidad de sentidos ya había trabajado en su día Zarb (Zarb, 1930; 1932). Resolvió este problema distinguiendo entre sentido literal principal, que es el intentado por el hagiógrafo, sentidos adaptados, que intenta el autor divino (también literales, aunque no principales) y sentidos espirituales, que son los comprendidos por los exégetas y previstos por Dios. Se acerca más a esta postura Philippe, cuando afirma que los misterios de la fe que Dios quiere revelar, además de la historia misma, forman parte de la intención del autor divino y, por tanto, pertenecen al sentido literal (Philippe, 1998: 18, nota 3; 25). Asimismo, fundándose en esa intención divina, Tábet había escrito que «el sentido literal de la Biblia goza de una gran riqueza de contenido, no agotable en la intencionalidad humana del hagiógrafo: para santo Tomás, abarca toda la verdad que rectamente puede ser encontrada en las palabras inspiradas» (Tábet, 1986: 178).

Considerar a Dios autor de la Escritura proporciona gran versatilidad hermenéutica al texto. En efecto, Dios no sólo posee poder para acomodar las palabras de la Escritura a aquello que quiere decir, sino incluso la misma realidad (res) significada por las palabras, las cosas por las cuales Dios se ha manifestado (Quodlibet VII, q. 6, a. 1, in c.; Ménard, 1964: 134; Roszak, 2019, 14-15). A estas realidades no siempre se alude en sentido recto, sino también en sentido figurado ${ }^{37}$.

Asimismo, Dios puede prever no sólo lo que el hagiógrafo quiere decir, sino incluso lo que interpretarán en el futuro los exégetas: «Aunque algunas verdades puedan ser adaptadas por los intérpretes de la Escritura pese a no haber sido consideradas por el autor [humano], no cabe duda de que el Espíritu santo sí las consideró y Él es el principal autor de la sagrada Escritura. En consecuencia, toda verdad

${ }^{35}$ "What Thomas does in practice by presenting multiple interpretations of the letter, he affirms in principle: the literal sense admits of many meanings. Recall the principle from De potentia: one ought not insist upon one's own interpretation to the exclusion of other interpretations which in their content are true in wich the circumstance of the letter is preserved" (Boyle, 2005: 5).

${ }^{36}$ «[...] verba prophetarum sic respiciebant praesens tempus, quod etiam in figuram futuri dicebantur» (S. Th. I-II, 102, 2).

${ }^{37}$ Bajo la lectura literal cae tanto la historia, como también la metáfora o la parábola $(S$. Th. I, 1, 9, in c.; a. 10, ad 3; Super Gal., 4, lect. 7), o sea, existe un sentido literal figurado (Parenti, 1975: 75ss.). Además, caen bajo el sentido literal la etiología y la analogía, esto es, la revelación de las causas de los hechos así como el poner de manifiesto la no contradicción de los pasajes entre sí ( $S$. Th. I, 1, 10, ad 2; I-II, 102, 2). 
que, sin interferir con la circunstancia del texto, puede ser adaptada a la sagrada Escritura, forma parte de su sentido ${ }^{38}$. De este pasaje se puede concluir que los sentidos espirituales del texto, aunque los ignore el autor humano, sí podrían considerarse auténticos sentidos literales del texto en cuanto el autor divino los conoce y los prevé (Gardeil, 1903: 438). Por este motivo, Philippe llega a decir que el sentido espiritual es en cierta manera literal (Philippe, 1998: 25). Para argumentar esta tesis, señala diferentes niveles en el término "místico" cuando lo usa santo Tomás: se podría hablar, como aquí, de místico como sinónimo de "espiritual" y opuesto a "literal", o como sinónimo de "figurativo" o "alegórico"; también se podría hablar de místico apelando al sentido profundo que Dios quiere revelar en las palabras que inspira y que sólo se aprecia si uno se acerca a ellas con la acogida de amorosa de la fe. Éste último es el uso propio del término cuando se refiere a la Escritura (Philippe, 1998: 22-25). La idea principal de Philippe parece ser, pues, la unidad fundamental entre la lectura literal y la espiritual en virtud de la inspiración. Esta tesis también la han defendido otros autores ${ }^{39}$. Podemos recordar aquí, por ejemplo, la consideración de Roszak quien insiste en la unidad de los distintos sentidos que cabe encontrar en un texto, haciendo así imposible toda arbitrariedad interpretativa. Siguiendo a K. Froelich, dicho autor afirma que "Tomás prácticamente nunca trata un solo sentido -por ejemplo, el literal-, sin atender también a los otros; su reflexión sobre los sentidos de la Escritura los combina formando uno solo. El sentido espiritual no tiene que ser explicado a continuación del otro (como si fuera algo añadido artificialmente); sólo es preciso ir más allá de la superficie (cortice) del sentido literal para descubrir lo que se esconde dentro» (Roszak, 2016: 486).

En definitiva, santo Tomás no sólo admite la interpretación que él llama "espiritual" ${ }^{30}$, sino que la considera congénita a la Escritura ${ }^{41}$. Llama sentido espiritual a aquel que abarca ciertas realidades de alguna manera relacionadas con las realidades significadas por las palabras de la Escritura: son las cosas mismas (res) las que están dotadas de un sentido mayor que el elucidado momentáneamente por el texto ${ }^{42}$.

${ }^{38}$ «Unde si etiam aliqua vera ab expositoribus sacrae Scripturae litterae aptentur, quae auctor non intelligit, non est dubium quin Spiritus sanctus intellexerit, qui est principalis auctor divinae Scripturae. Unde omnis veritas quae, salva litterae circumstantia, potest divinae Scripturae aptari, est eius sensus» (De potentia, q. 4, a. 1, in c.).

${ }^{39}$ "Tommaso non separa il senso "spirituale" dal senso "letterale", che sono l'uno nell'altro, anzi a un certo punto sembra che tutti i sensi della Scrittura sono senso "letterale"» (Di Marco, 1978: 62). "The "Spirit" of Scripture was hidden behind or added to the text. For Thomas the letter and spirit could no more be separated than matter and form, or body and soul» (Paretsky, 1994: 563).

${ }^{40}$ También habla de un sensus mysticus, quizá traducible por "simbólico" (Super I Tim., 5, lect. 3), o quizá "secreto" o "escondido" (ibíd., 3, lect. 2).

${ }^{41}$ "De necessitate sacrae Scripturae» (Quodlibet VII, q. 6, a. 5, arg. 3). «Hoc enim ad dignitatem divinae scripturae pertinet, ut sub una littera multos sensus contineat» (De Potentia, q. 4, a. 1, in c.).

${ }^{42}$ «Sensus isti non multiplicantur propter hoc quod una vox multa significet; sed quia ipsae res significatae per voces aliarum rerum possunt esse signa» $(S$. Th. I, 1, 10, ad 1). «Avec lui [sc. le sens 
Así, mientras el sentido literal permite conocer la historia, el sentido espiritual explica el significado profundo que posee dicha historia. Esta forma de ver la exégesis exige unos planteamientos metafísicos y gnoseológicos precisos: una prioridad de las cosas frente al significado y una prioridad del significado frente a las palabras (Roszak, 2018; Roszak, 2014: 317-318).

Una tesis capital es que el sentido espiritual «se funda sobre el literal y lo supone» ${ }^{43}$. Según Tomás, no hay nada contenido en él que no aparezca expresamente en el literal en alguna parte de la Escritura (S. Th. I, 1, 10, ad 1). De este modo, aunque se puedan hacer muchas lecturas "espirituales" de una de las realidades significadas por un texto, éstas no serían legítimas si no hubiera revelado Dios de manera patente qué quiere decirnos mediante el sentido literal en otro pasaje. En consecuencia, la delimitación es bastante clara, puesto que el sentido literal parece más accesible al lector que el espiritual, el cual presupone un marco de sentido más amplio. No hay, pues, posibilidad alguna de arbitrariedad ni de confusión, puesto que no son admisibles todos los sentidos espirituales siempre ni de cualquier manera, sino que están en relación con las cosas señaladas por la letra y no todas pueden ser signo de cualquier otra cosa (Quodlibet VII, q. 6, a. 5, ad 3).

El sentido espiritual puede ser alegórico, moral o anagógico ${ }^{44}$. El alegórico se aplica a aquellos textos del Antiguo Testamento que se pueden leer de modo tipológico, en cuanto, además de explicar una verdad histórica, están anunciando a Cristo y todo el régimen de la Nueva Alianza. El sentido anagógico hace referencia a los hechos de la vida de Cristo o a la obra de Dios en Cristo, en cuanto tales acontecimientos de la Nueva Ley son signo de lo que ha de suceder en el futuro. El sentido moral supone que tales acontecimientos son signos de la acción propia del cristiano. Esta división de los sentidos espirituales no se debe, por tanto, a un deseo arbitrario del exégeta, sino a la voluntad providencial de Dios, que ha ordenado las realidades en el contexto de la historia de la salvación, de la que Cristo es el centro (Mailhiot, 1959: 640-641).

Aunque la exégesis espiritual no resulte novedosa en el panorama medieval, la articulación de los sentidos de la escritura podría constituir una de las grandes aportaciones de santo Tomás a la historia de la exégesis (Venard, 2003: 40). En la mente del Aquinate, este problema hermenéutico alude a una inquietud de fondo que, de vez en cuando, aflora en su obra. Él la expresa aludiendo a una herejía atribuida

spirituel] nous sommes en présence d'une similitude mise intentionnellement par Dieu au coeur des réalités: une signification, dérivant non plus des voces, mais des res, des réalités signifiés par les mots. En effet, Dieu [...] a pu disposer les événements historiques, les personnes et les réalités elles-mêmes, de telle manière qu'ils fussent des symboles des réalités mystérieuses à venir» (Mailhiot, 1959: 635).

${ }^{43}$ «Super litteralem fundatur, et eum supponit» $(S . T h$. I, 1, 10, in c.; cf. ibíd. I, 102, 1, in c.; Quodlibet VII, q. 6, a. 1, ad 3).

${ }^{44}$ Cf. Quodlibet VII, q. 6, a. 2, in c.; Super Gal., 4, lect. 7. 
a Teodoro de Mopsuestia, que consiste en afirmar que el Antiguo Testamento no dice nada expresamente acerca de Cristo ni de la Iglesia, sino que, si se aplica a éstos, es por industria de los intérpretes: «[...] todas las profecías del Antiguo Testamento fueron dichas aludiendo a empresas determinadas, de forma que los apóstoles y los evangelistas las aplicaron al ministerio de Cristo sólo por apropiación, como lo que se dice sobre un hecho puede adaptarse a otro» ${ }^{45}$. Por el contrario, el Aquinate asume el método tradicional, que él recibe de Jerónimo ${ }^{46}$, el cual ve la Escritura en unidad a causa de su autor divino, pudiendo así descubrir a Cristo tras las figuras del Antiguo Testamento: «La sagrada Escritura se interpreta con el mismo espíritu por el que está fundada ${ }^{47}$. Como acabamos de ver, toda su doctrina acerca de la pluralidad de sentidos viene a justificar este principio teológico de interpretación.

Santo Tomás procura introducir en su exposición las diferentes lecturas tradicionales de un mismo texto ${ }^{48}$, aunque suele decir cuál le parece mejor ${ }^{49}$. Teniendo en cuenta que toda la Escritura tiene sentido en virtud del fin por el cual ha sido escrita, a saber, conocer la verdad necesaria para la salvación (Quodlibet vII, q. 6, a. 1, in c.), le interesa recogerlas por su valor doctrinal, aunque sólo se trate de sentidos espirituales, puesto que en algún otro lugar -como decíamos- queda expuesta literalmente esa misma doctrina ${ }^{50}$. No obstante, a veces parece que esa recopilación exhaustiva de interpretaciones se debe más bien a la insuficiencia explicativa de cada una de ellas, de modo que se propone cada una a modo de hipótesis ${ }^{51}$.

${ }^{45}$ «Excluditur error Manichaeorum, qui dixerunt nullas prophetias in veteri testamento praecessisse de christo, ut Augustinus narrat in lib. Contra Faustum [12, 1ss., PL 42, 253ss.], et Theodorum Mopsuestenum [In Joelem, 2, 28-32, PG 66, 232-233], qui dixit omnes Prophetias Veteris Testamenti esse de aliquo negotio dictas, per quamdam tamen appropriationem esse adductas ab Apostolis et Evangelistis ad ministerium Christi: sicut ea quae dicunt in uno facto, possunt adaptari ad aliud factum» (Super Io., 12, lect. 7, \$1705; cf. Super Psalmos, Pr.).

${ }^{46}$ En el Proemio a su comentario sobre los salmos alude al libro de Jerónimo sobre Ezequiel, si bien sabemos que también está recogido este principio en el Proemio de la Glosa a este libro (PL 113, $844 \mathrm{~B}-\mathrm{C})$. Tales afirmaciones supusieron históricamente el florecimiento de la exégesis alegórica.

${ }^{47}$ «Sacra Scriptura eodem spiritu interpretatur quo est condita» (Super Rom., 12, lect. 2).

${ }^{48}$ Por ejemplo, sólo en prólogo de Juan, nos encontramos con numerosos pasajes dedicados a mostrar cuáles son las lecturas de los comentarios patrísticos que le parecen más relevantes en cada caso: cf. Super Io., 1, lect. 1, $\$ \$ 29-32, \$ \$ 35-38, \$ 40$, $\$ \$ 46-52$, $\$ \$ 55-59$; lect. 2, $\$ \$ 69-72$, $\$ \$ 77-78$, $\$ \$ 84-88$; lect. $2-3$, $\$ \$ 90-100$; lect. 3, $\$ \$ 102-103, \$ 105$; lect. 4, $\$ 119$; lect. 5 , $\$ 130$, $\$ 135$; lect. 6 , $\$ 158$; lect. 7, \$165, \$173; lect. 8, \$182; lect. 9, \$197, \$198; lect. 10, \$204, \$206.

${ }^{49}$ Cf. Super Io., 1, lect. 1, \$59; lect. 6, \$143; lect. 14, \$276... Parece que la mejor lectura es aquella que ayuda a elucidar más claramente el sentido literal: cf. ibíd., 11, lect. 2, \$1491; Super Rom., 3, lect. 4; 9, lect. 9 .

${ }^{50}$ En el Comentario de san Juan disponemos de varios ejemplos de esta manera de aludir a los sentidos espirituales confirmándolos con el sentido literal de otros textos: cf. Super Io., 1, lect. 13, $\$ 250$; lect. $15, \$ 289, \$ 290$; lect. 16 , $\$ \$ 322-323$; 11, lect. 2 , $\$ 1483$; lect. 4, $\$ 1510$; 13, lect. 3, $\$ 1771$.

${ }^{51}$ Cf. Super Io., 6, lect. 4, \$923; 10, lect. 4, \$1422 (véase Super Rom., 3, lect. 3), Super Io., 16, lect. 7, \$\$2149-2152. 
En la Lectura super Ioannem encontramos algunas interpretaciones espirituales expuestas con bastante sobriedad ${ }^{52}$. A pesar del cuidado desplegado para descubrir el sentido literal, no se deja de traer el sentido místico a colación, puesto que ayuda a poner de manifiesto la fe. De este modo, se conserva la riqueza de la tradición, se respeta el sentido obvio del texto y se acepta toda buena lectura, con tal que quede claro qué rango de revelación ostenta. La exégesis de santo Tomás acaba siendo realista y exhaustiva: se apoya en las palabras, en la gramática, el contexto; se deja ayudar por los padres, pero los somete a crítica. Además, no olvida en ningún momento que el texto bíblico se refiere a la realidad y, por consiguiente, le lleva a examinar las causas de las conductas de las personas que aparecen reflejadas, la naturaleza de las cosas, la vida del Señor...

\section{2. EXÉGESIS DIALÉCTICA}

En tiempos de santo Tomás, habían llegado a la Universidad de París nuevas formas de investigación. En el campo de la exégesis esto significó la multiplicación de divisiones, concordancias, consonancias rítmicas... En particular, las divisiones en miembros distintos es algo específico de la exégesis dialéctica del siglo XIII. Resulta verdaderamente sorprendente al lector de los comentarios tomasianos este afán por dividir el texto, pero tampoco se puede dejar al margen aunque esa forma de investigar nos resulte ajena, incluso forzada a veces. La división es también el método que utiliza el Aquinate para interpretar a Aristóteles, en quien halla todos los elementos de un razonamiento que puede pasar desapercibido y que en la lectura cuidadosa del comentarista resulta explicitado. Esta minuciosa operación es trasladada a los comentarios sobre la Escritura, en la cual reconoce enunciaciones, demostraciones e incluso, en ocasiones, las premisas mayor y menor de los silogismos ${ }^{53}$. Al comentar un texto siente que la división es imprescindible para captar el núcleo del mensaje y percibir así la articulación entre el sentido profundo del texto, la intención del autor y la unidad compleja de la obra (Rossi, 1994: 540; Boyle, 2005: 7).

Manifiesta una preocupación constante por extraer la doctrina del texto que está investigando a partir del procedimiento de la síntesis y el análisis ${ }^{54}$. El análisis

6, $\$ 1469$.

${ }^{52}$ Cf. Super Io., 1, lect. 16, $\$ 310 ; 2$, lect. 2, $\$ 373$; 4, lect. 1, $\$ 565$; 5, lect. 2, $\$ 728 ; 10$, lect.

${ }^{53}$ Cf. Super Io., 6, lect. 7, $\$ 975$; Super Rom., 8, lect. 5 y 6.

${ }^{54}$ Chenu expone cuáles son, en su opinión, los momentos del método del Aquinate: 1. Búsqueda en el texto de los elementos que despiertan el interés del exégeta ordenándolos con divisiones. 2. Fijación del contenido del texto superando las dificultades de los términos y expresiones. 3. Comprensión de los términos y los conceptos mediante el instrumental de pensamiento que maneja el exégeta. 4. Búsqueda de las razones que explican todos los aspectos analizados. 5. Paso de la lectio a la quaestio, es decir, partir del texto bíblico para solucionar alguna aporía teológica (Chenu, 1924: 213-216). Otra enumeración de estos pasos la debemos a J. Margarido: 1. Determinación del significado de los términos 
comienza al tratar de relacionar la cuestión abordada con lo que ha quedado dicho antes, siempre que se pueda. Emplea para este fin términos escogidos, como supra, superius o postquam. A continuación procede a dividir y subdividir en partes que introduce con expresiones muy personales: hic facit duo o tria facit. En general, es en la segunda división cuando aparece esta manera de expresarse (Mandonnet, 1929: 67).

Por lo demás, tampoco el interés de santo Tomás está ceñido a la división, sino que también se ocupa en buena medida de la síntesis (Gardeil, 1903: 453; Dauphinais, 2005: 312, 317). Precisamente el valor que poseen sus divisiones es permitir obtener el contenido íntegro del texto. Siempre busca la manera de mostrar cómo se encadenan unos miembros con otros, por razón de la unidad de las ideas ${ }^{55}$. Hasta tal punto trata de buscar la unidad sistemática de la doctrina transmitida por el Autor divino de la Escritura, que a veces no parece tener en cuenta suficientemente la variedad de géneros literarios y procedencias de los textos, ni la espontaneidad expresiva de los autores humanos. Sin embargo, la construcción orgánica de los textos elaborados por el Aquinate significa un punto de originalidad respecto a los autores precedentes. No intenta tan sólo sistematizar las interpretaciones patrísticas sino que busca el mensaje que el autor sagrado quiere comunicar.

Hereda santo Tomás de la exégesis del siglo XII la calificación de los libros bíblicos según la materia, la utilidad (o finalidad: Super Tit., 3, lect. 2), el modo y la intención del autor. Sin embargo, incorpora la definición de la obra literaria según las cuatro causas de Aristóteles. Esta es una novedad que comparte con san Alberto Magno y san Buenaventura.

de la Escritura y confrontación con la terminología teológica. 2. Deseo de penetración en la intención del autor. 3. Examen de las contradicciones con otros textos de la Escritura. 4. Comparación con textos que se complementan. 5. Búsqueda del valor doctrinal del texto. 6 . Reflexión de cada texto a la luz de la totalidad de la revelación, para llegar a un significado más pleno. 7. Comparación de la doctrina con las ideas acertadas de los padres o erradas de los herejes. 8. Reconocimiento de la legitimidad de otras interpretaciones (Margarido, 1978: 352). Emery, por su parte, considera que el Aquinate se inspira en la doctrina de Hugo de san Víctor, que distingue tres niveles de exégesis: littera (análisis textual, gramatical y lingüístico), sensus (significado de cada parte) y sententia (la afirmación teológica en cuestión). Sobre esto descubre los siguientes pasos: 1 . Precisiones preliminares sobre el vocabulario bíblico. 2. Razones por las que el hagiógrafo usó tales o cuales palabras. 3. Precisiones doctrinales preliminares o complementarias. 4. Indicación y refutación de las herejías contrarias. Finalmente, Emery se opone a otros autores al comentar que no siempre se sigue la estructura formal de la quaestio, sino que, junto a ella, existe asimismo el comentario literal doctrinal, pero también una forma combinada de ambos (Emery, 2005: 45-46). En el Comentario de san Juan, Weisheipl ha enumerado otras etapas sucesivas: 1. Determinación del sentido literal y los espirituales. 2. Explicación de esos sentidos. 3. Refutación de los errores. 4. Confirmación de la fe de la Iglesia (Weisheipl, 1980: 14).

${ }_{55}$ El procedimiento de división posee tres momentos: en primer lugar, se fracciona el texto en unidades mínimas de contenido semántico; en segundo lugar, trata de definir cada parte, haciendo un esfuerzo hermenéutico por comprender qué significa cada una de ellas; en tercer lugar, se muestra la unidad de contenido del conjunto dando la definición de las divisiones mayores y menores (Rossi, 1994: 540-541). 


\section{3. EXÉGESIS TEOLÓGICA}

Como decíamos, la preocupación dominante de santo Tomás y de sus contemporáneos es encontrar en el texto bíblico las enseñanzas relativas al dogma y a la moral. Todo su esfuerzo por desentrañar el contenido literal del texto está enderezado a obtener una teología bíblica, que es parte esencial de la doctrina sagrada ${ }^{56}$. Esto significa que el Aquinate ve en la Escritura el lugar teológico por excelencia, donde se manifiesta la doctrina, se esclarecen las objeciones, se refuta a los herejes...

En ocasiones, el exégeta se encuentra con un texto escriturístico aparentemente contradictorio con algún punto dogmático. Eso le puede llevar a "dudar» (Super Io., 4, lect. 6, \$666) o a "preguntarse» por el texto ${ }^{57}$. Para santo Tomás, estas cuestiones no son accidentales o foráneas a la exégesis, porque ante todo busca la penetración racional del texto revelado. Estudia el problema en su misma fuente, allí donde surge la disputa que también aborda en las obras sistemáticas ${ }^{58}$. La similitud es tan clara que a veces incluso la estructura del comentario de la Escritura se asemeja a la de una cuestión de Teología ${ }^{59}$. Al contemplar los textos, parece tener siempre en mente alguna controversia teológica, de forma que de vez en cuando declara que una perícopa prueba cierta tesis o define alguna verdad dogmática.

La exégesis de santo Tomás se funda, pues, en una visión creyente de la Escritura, lo cual le lleva a interpretar la Escritura, en primer lugar, a través de ella misma.

${ }^{56}$ Para santo Tomás, la búsqueda de la doctrina teológica en la Escritura no consiste en yuxtaponer el dogma sobre la exégesis, sino más bien percibe que el contenido de la fe, incluido el desarrollo del dogma, se encuentra latente en la Escritura: «St. Thomas integrates exegesis and speculative reflection in a complex unity. Is it not sufficient to say that St. Thomas goes from biblical exegesis to theology, because speculative reflection intervenes to offer the profund sense of the text that the exegesis is looking for. Questions and theological precisions are neither juxtaposed nor superimposed on biblical exegesis, but they are integred into biblical exegesis, in such a way so as to be fully part of the exegesis practiced by St. Thomas» (Emery, 2005: 48). De hecho, el contenido de la Escritura se identificaría sin más con la doctrina teológica: «Sacra doctrina and sacra scriptura may be used interchangeably as synonims [...]. The function of sacra doctrina is to clarify, vindicate and transmit the truth given in scripture, but it does so through the ratio of the theologian, reason, that is, illuminated by faith» (Persson, 1970: 267).

${ }^{57}$ Cf. Super Io., 1, lect. $1, \$ 55, \$ 56$; lect. 4, $\$ 123$; lect. 7, $\$ \$ 170-172$; lect. 14 , $\$ 275$, etc.

${ }^{58}$ Por ejemplo, véase la quaestio sobre la visión de Dios incluida en el prólogo de Juan: Super Io., 1, lect. 11, $\$ \$ 210-213$; cf. S. Th. I, 12. Recuérdese que, en realidad, la Summa Theologiae tiene como motivación principal (propositum) mostrar la doctrina siguiendo el orden adecuado para aprenderla en lugar de seguir la exposición de los libros: «[...] ea quae sunt necessaria talibus [doctrinae novitiis] ad sciendum, non traduntur secundum ordinem disciplinae, sed secundum quod requirebat librorum expositio» (S. Th., Prologus).

${ }^{59}$ Tan sólo en el prólogo de san Juan, podemos distinguir objeciones a la cuestión, una contradicción o un argumento de autoridad (sed contra), la demostración del maestro (respondeo), las respuestas a las objeciones (ad...): cf. Super Io., 1, lect. 7, \$\$166-172; lect. 11, \$\$210-214. Véase además ibíd., 10, lect. 4, \$1422. Aparecen razones de conveniencia teológica en ibíd., 3, lect. 1, \$\$442-443; 12 , lect. $5, \$ 1673$. 
Siempre se preocupa por encontrar los textos paralelos al que está comentando, aunque la cita suela ser traída de memoria y sea evocada en función de la semejanza léxica de los términos o por razón de las ideas reflejadas ${ }^{60}$. Sin embargo, no se da una profusión de citas bíblicas puramente ornamentales y gratuitas: santo Tomás escoge bien las referencias que hace y trata de que verdaderamente aclaren el texto y sostengan sus afirmaciones ${ }^{61}$. Además, siempre se cuida de mostrar las divergencias internas del texto y se esfuerza por solucionar los problemas hermenúticos que le $\operatorname{asaltan}^{62}$.

\section{4. EXÉGESIS TRADICIONAL}

Movido por una concepción teológica de la autoridad, el Aquinate investiga la Escritura dejándose ayudar por la tradición ${ }^{63}$. En cuanto maestro de Teología, está obligado al uso de la Glosa. Además, él mismo amplía este recurso a la entera tradición, extendiendo al máximo la investigación de los comentarios patrísticos (Geenen, 1946: 701-704). Además, no sólo se sirve de florilegios de textos de los padres, sino que acude a los textos originales, de forma que, tanto por su criterio como por su erudición, supera a todos sus coetáneos (Vosté, 1937: 420; De Miguel y Sicilia, 1975: 145-146; Geenen, 1975: 65). Tanto es así que el Comentario de san Juan, el cual ha sido calificado como «uno de los más tradicionales de santo Tomás» (Spicq, 1946: 722), parece intentar poner en orden los pensamientos de san Agustín y san Juan Crisóstomo así como los de los otros padres recogidos en la Catena aurea que el mismo santo Tomás había compuesto. Esta obra fue sin duda usada para alcanzar una perfecta inteligencia teológica del cuarto evangelio durante la elaboración del Comentario, es decir, debía de tenerla a mano al exponer el texto en clase (Mandonnet, 1929: 138-139, 145, 491-496, 519; Conticello, 1990; Emery, 2005: $51,59)$. En este escrito se manifiesta totalmente su inquietud patrística, haciendo un esfuerzo considerable de documentación que le llevó incluso a solicitar nuevas traducciones de los autores griegos ${ }^{64}$.

${ }^{60}$ Cf. v. gr. Super Io., 18 , lect. 5 , $\$ 2330$, donde se cita Mi 2,1 y Jb 24,14 .

${ }^{61}$ Por ejemplo, es cierto que Jesús no ha venido para acusar de los pecados (Jn 5,45; cf. Super Io., 5, lect. 7, \$834), porque en otros lugares se dice que no ha venido a condenar sino a salvar (Jn 3,17; cf. Heb 12,24, Rm 8,33).

${ }^{62}$ Cf. Super Io., 9 , lect. 4, $\$ 1360 ; 11$, lect. $5, \$ 1532 ; 13$, lect. 3, $\$ 1783 \ldots$ En todos estos casos, siempre resuelve las dificultades leyendo el tenor de cada texto en su lugar y luego distinguiendo los conceptos para precisarlos.

${ }_{63}$ «Oportet enim non solum conservare ea quae in sanctis Scripturis sunt tradita, sed et ea quae dicta sunt a sacris doctoribus, qui sacram Scripturam illibatam conservaverunt» (In De div. nom., 2, lect. 1). La razón de la autoridad de los padres, como vemos, se funda en su proximidad con la Escritura, como «testigos de la fe» (De Miguel y Sicilia, 1979: 179) y «garantes de la Tradición» (De Miguel y Sicilia, 1975: 129).

${ }^{64}$ "Ut magis integra et continua praedicta sanctorum expositio redderetur, quasdam expositiones Doctorum graecorum in latinum feci transferri» (Catena in $M c$., Dedicatio). A esto se debe que 
Hasta tal punto los medievales estimaban a los padres que veían en el conjunto de sus escritos una manifestación del Espíritu de Dios. Por esto habían de exponerse sus afirmaciones de forma reverencial ${ }^{65}$. Además, en santo Tomás, la tradición se refleja en una exégesis "eclesiástica". Para él, la autoridad definitiva es la opinión y el uso de la Iglesia, por encima incluso de las sentencias de los doctores ${ }^{66}$. La razón de ello es que la misma autoridad de los padres depende de la autoridad de la Iglesia ${ }^{67}$.

La lectura de la Escritura llevada a cabo por santo Tomás hace también continua referencia a los errores de los herejes ${ }^{68}$. Esto no es sino consecuencia de su afición a la exégesis patrística (Emery, 2005: 55). Considera que la lectura teológica de los textos debe conducir necesariamente a la refutación de las doctrinas opuestas a la fe, de manera que las trata como si fueran contemporáneas, con una especie de anacronismo que al lector moderno podría resultar desconcertante. En el Comentario de Juan podemos encontrar menciones al «error de algunos» (Super Io., 2, lect. 2 , $\$ 370$; 5, lect. 5, \$783, etc.), al «error de los herejes» (ibíd., 19, lect. 2, \$2396), o la sola mención de los herejes en general ${ }^{69}$. De igual modo, se refutan los «errores de los filósofos» (ibíd., 1, lect. 1, \$65) y aun a los «herejes de la academia» (ibíd., 4, lect. 4, \$648) o se resuelve la «vana investigación de los gentiles» (ibíd., 1, lect. $5, \$ 139)$.

No sólo santo Tomás, sino también muchos otros autores de su época, a la hora de comentar la sagrada página, echan mano de las obras de autores paganos.

aparezcan en la Catena autores tan poco conocidos en su tiempo como Teofilacto. Por otra parte, calificó de vitiosa la traducción del Crisóstomo que había usado al principio (Catena in Mt., Dedicatio), por lo que para la Catena in Io. prefiere servirse de la traducción de Burgundio de Pisa (Conticello, 1990: 65). Sobre esta obra en concreto consta la anécdota referida por Tocco acerca de cuánto más preferiría el Aquinate disponer de una buena traducción de las homilías del Crisóstomo sobre Mateo que poseer toda la ciudad de París (Vosté, 1937: 427).

${ }^{65}$ «Si qua in dictis antiquorum doctorum inveniuntur quae cum tanta cautela non dicantur quanta a modernis servatur, non sunt contemnenda aut abiicienda, sed nec etiam ea extendere oportet, sed exponere reverenter» (Contra errores Graecorum, 1, Pr.; cf. S. Th. III, 4, 3, ad 1). «[...] nimis praesumptuosum videretur asserere tantos Ecclesiae doctores [sc. Augustinum et Gregorium Nazianzenum] a sana doctrina pietatis deviasse» (De substantiis separatis, 18).

${ }^{66}$ Cf. Super Io., 2, lect. 1, \$337; lect. 2, \$376; 21, lect. 6, \$2656 (Santi, 1994: 527-530).

${ }^{67}$ «Et ipsa doctrina Catholicorum Doctorum ab Ecclesia auctoritatem habet: unde magis standum est auctoritati Ecclesiae quam auctoritati vel Augustini vel Hieronymi vel cuiuscumque Doctoris» (S. Th. II-II, 10, 12).

${ }_{68}$ «Fuit autem mea intentio in hoc opere non solum sensum prosequi litteralem, sed etiam mysticum ponere, interdum etiam errores destruere, necnon et confirmare catholicam veritatem» (Catena in Mt., Dedicatio). En el que probablemente sea su discurso inaugural en la Universidad parisina (Weisheipl, 1994: 427), el Doctor Angélico declaró: «Doctores Ecclesiae in defensionem fidei debent esse contra errores» (Rigans montes, 2).

${ }^{69}$ Existen dos listas de herejes con sus nombres y el número de apariciones (Spicq, 1946: 723; Cai, 1952: 489-491). Entre éstos, los arrianos son increpados más frecuentemente: su inmensa ceguera les impide entender lo que los mismos judíos contemporáneos de Jesús comprendieron, a saber, que Cristo era el Hijo de Dios (Super Io., 5, lect. 2, \$742). 
Se los considera autoridades, no comparables a la Escritura ni a los padres, pero sí revestidas de prestigio ${ }^{70}$. Sin embargo, el Aquinate es mucho más comedido en el uso de estas citas que otros autores eclesiásticos, como por ejemplo su maestro san Alberto Magno (Smalley, 1972: 418)

El uso de los paganos permite precisar más los conceptos que aparecen en el texto, de forma que ayuden a la inteligencia de la fe. Podría pensarse, no obstante, que emplear la filosofía -pensemos, verbigracia, en la investigación por las cuatro causas- puede aportar al texto bíblico un significado anacrónico o artificioso, ajeno a la letra y la intención del autor. Pero, en realidad, no se falsea el sentido sino que estas fórmulas «expresan los conceptos que en todo tiempo y lugar ocupan el pensamiento de los hombres» (Spicq, 1946: 724). Además, santo Tomás no es esclavo del utillaje filosófico, sino que lo ve como un instrumental para abrir el significado del pensamiento mismo de Dios reflejado en la Escritura (Tábet, 1980; Casciaro, 1974; Cirillo, 1988: 53-62), como se aprecia de manera particular en la exégesis del prólogo de san Juan (Philippe, 1998: 12; Bonino, 2004: 165-166). Usando una imagen joánica, santo Tomás explica que la asunción de las enseñanzas de los paganos en Teología no significa mezclar lo sagrado con lo profano, sino más bien transformar la enseñanza humana en doctrina sagrada, como Jesús transformó el agua en vino (Super De Trinitate, 1, q. 2, a. 3, ad 5). Además, esta incorporación del saber pagano en la doctrina cristiana no escapa al designio divino, puesto que es el Espíritu santo quien inspira toda verdad, incluso entre los infieles ${ }^{72}$.

\section{5. EXÉGESIS VERBAL}

Como dijimos, la exégesis tomasiana echa mano continuamente de unas interpretaciones etimológicas que no siempre aciertan con el significado original. Ello corresponde a una comprensión de los términos como expresión bastante exacta de la realidad a la que se refieren. Esta es una doctrina en buena medida común durante la antigüedad bíblica e incluso en el mundo griego. El mismo santo Tomás

${ }^{70}$ «Non recipit ea propter auctoritatem dicentium; sed propter rationem doctorum unde bene dicta recipit et alia respuit» (Super De Trinitate, 1, q. 2, a. 3, ad 8).

${ }^{71}$ Aristóteles es mencionado sólo catorce veces en todo el Comentario de san Juan y una de ellas es para refutarlo (Super Io., 1, lect. 1, \$65). Sin embargo algunos autores dan importancia quizá algo excesiva a la citación del Filósofo, quizá por ser el primer autor referido en el Comentario (Philippe, 1998: 11, nota 5; Paretsky, 1994: 562). Por lo demás, aparecen sólo una vez Máximo Valerio, cuatro veces Cicerón, dos veces Platón y los platónicos, y otras dos Demócrito y los estoicos.

${ }^{72}$ «Dicit Ambrosius [cf. P. Lombardus, In I ad Cor., 12, 1-3, PL 191, 1651A; Ambrosiaster, In I Cor., 12, 3, PL 17, 258C], quod omne verum a quocumque dicatur a Spiritu sancto est» (Super Io., 14, lect. 4, \$1916). 
entiende que la palabra es representativa de la realidad a la que se refiere. En el Comentario de san Juan son frecuentes estas etimologías ${ }^{73}$.

\section{REGLAS HERMENÉUTICAS}

En ningún momento de su obra hace referencia santo Tomás de modo explícito a las siete reglas de Ticonio que san Agustín recoge en su libro De doctrina christiana (3, 30-37, PL 34, 81-90) y que están presentes en la exégesis de la época. Por ejemplo, son asumidas por Hugo de san Víctor, «que es el único predecesor de santo Tomás en haber formulado unas reglas de hermenéutica» (Spicq, 1946: 728). De hecho, el Aquinate sigue muchas veces esas reglas, aunque también formula sus propias declaraciones de principios, que vamos a intentar exponer aquí.

Para empezar, para él es crucial prestar atención a la persona del exégeta (Manresa Lamarca, 2018: 331-388). Éste necesita ejercicio y largos estudios (S. Th. II-II, 1, 9, ad 1), pero también ha de implorar el auxilio divino, puesto que es Dios mismo quien ayuda a entender y exponer los misterios recónditos de la Escritura ${ }^{74}$ : las palabras divinas son tan incomparables con la comprensión humana que sólo podemos entenderlas si Dios mismo nos las revela (Super Io., 13, lect. 5, \$1816). En su Principium Rigans montes (cap. 2) expone los requisitos que debe guardar el maestro de la Escritura: llevar una vida sobresaliente, dejarse iluminar para poder iluminar a otros y estar preparado para hacer frente a los que contradigan la sabiduría, es decir, la teología. Efectivamente, lo que distingue la ciencia sagrada de otra forma de conocimiento es que "en ella no sólo se ofrecen verdades para ser consideradas con la razón, como en la geometría, sino para asentir mediante la voluntad [...]. Por eso, en otras ciencias, basta que el hombre posea la perfección que corresponde a su inteligencia; en ésta, se requiere también la rectitud de los afectos ${ }^{75}$.

${ }^{73}$ "Philippus enim interpretatur "os lampadis". Praedicatores autem sunt os Christi; Ier. 15,19: "si separaveris pretiosum a vili, quasi os meum eris". Christus autem lampas est; Is. 42,6: "Dedi te in lucem Gentium" etc. Convenit etiam ei quantum ad locum "Qui erat a Bethsaida", quae interpretatur "venatio", quia praedicatores venantur eos quos ad Christum convertunt; Ier. 16,16: "Mittam eis piscatores, et piscabuntur eos". Item "Galilaeae", quae interpretatur "transmigratio", et Gentiles ad praedicationem Apostolorum transmigrati sunt de statu gentilitatis ad statum fidei» (Super Io., 12, lect. 4, \$1633). Ibíd., 1, lect. 4, \$114: Ioannes, ibíd., 11, lect. 4, \$1508; 12, lect. 1, \$1592: Bethania; ibíd., 11, lect. 7 , \$1574: Caiphas; ibíd., 12, lect. 1, \$1601: Iudas, etc.

${ }_{74}$ "Quos instruimus verbo, iuvemus orationum suffragio, quia sermo divinus maxime habet effectum in cordibus auditorum, cum oratione fulcitur, per quam divinum auxilium imploratur» (Super Io., 17, lect. 1, \$2178; cf. In Threnos, Pr.).

${ }^{75}$ «Hoc enim habet sacrae Scripturae doctrina, quod in ipsa non tantum traduntur speculanda, sicut in geometria, sed etiam approbanda per affectum. Unde Matth. 5,19: "qui autem fecerit et docuerit", et cetera. In aliis ergo scientiis sufficit quod homo sit perfectus secundum intellectum, in istis vero requiritur quod sit perfectus secundum intellectum et affectum» (Super Heb., 5, lect. 2). "Haec scripta sunt ut credatis quia Iesus Christus est Filius Dei, et ut credentes vitam habeatis in nomine eius". Ad hoc enim est tota Scriptura Novi et Veteris Testamenti» (Super Io., 20, lect. 6, \$2568; cf. Tábet, 1979: 223-229). 
El exégeta debe juzgar siempre que la Escritura es veraz. Para santo Tomás la Escritura no puede contener nada falso bajo el sentido literal (S. Th. I, 1, 10, ad 3; S. Th. I, 68, 1; De potentia, IV, 1; Aranda, 1977). No obstante, puede haber una contradicción aparente entre una aserción de la Escritura y otras afirmaciones verdaderas, pero no por ello se debe pensar que el texto sagrado esté enseñando algo evidentemente falso ${ }^{76}$. En este punto coincide plenamente con san Agustín (De Genesi ad litteram, 1, 18-19.21, 36-39.41, PL 34, 260-262). Además, sostiene la regla de la analogía de la fe, también agustiniana: «Hay analogía cuando se aprecia que la verdad de una escritura no está en contradicción con otra» ${ }^{77}$.

El intérprete, fundado en la veracidad de la Escritura, ha de solucionar las aparentes antinomias bíblicas, tal como hace él mismo, por ejemplo, cuando armoniza los relatos de las apariciones del resucitado (S. Th. I, q. 55). En particular, en el Comentario de san Juan santo Tomás aborda los problemas que presenta la así llamada "cuestión joánica"78. En consecuencia, intenta localizar el bautismo de Jesús respecto a las tentaciones del desierto o bien las bodas de Caná y los años de vida pública en relación con los sinópticos (Super Io., 2, lect. 1, \$337). De este modo, los sinópticos comenzarían su narración a partir de la encarcelación del Bautista y Juan completaría su testimonio con datos de una época precedente (ibíd., 2, lect. 2 , $\$ 367 ; 3$, lect. 4 , $\$ 504$; 4, lect. $1, \$ 557 ; 12$, lect. 3 , $\$ 1626$ ). El cuarto evangelista habría reconstruido los hechos con un orden histórico más preciso y no según el orden de los recuerdos, que es el seguido por los sinópticos (ibíd., 12, lect. 1, \$1597). Juan disponía de mejor perspectiva puesto que su evangelio debió de ser escrito tras la muerte de Pedro (ibíd., 21, lect. 4, \$2632) y de todos los apóstoles (ibíd., 21, lect. 6, \$2655). También explica la aparente oposición entre Jn 12,4 y Mt 26,8 en virtud del «uso» de Mateo (ibíd., 12, lect. 1, \$1606) y aborda la difícil y controvertida cuestión de la fecha exacta de la Cena (ibíd., 18, lect. 5, \$2330-2334). Por último, detalla el desarrollo histórico de las negaciones de Pedro (ibíd., 18, lect. 4, \$2326) y sitúa a las mujeres que estaban junto a la Cruz (ibíd., 19, lect. 4, \$\$2435-2436).

El exégeta debe buscar en cada caso cuál es el "buen sentido" (Gardeil, 1903: 442ss.; Roszak, 2017). No cabe hacer una exégesis demasiado pegada a la letra (es decir al "sentido recto"), porque también puede llevarnos al error. Hace falta cierta capacidad de apreciación de los datos que permita captar el sentido exacto que

${ }^{76}$ «Sciendum est, quod Nicodemus voluit obiicere contra verba salvatoris. Sed tamen obiectio eius derisibilis est, quia Christus loquitur de regeneratione spirituali, hic autem obiicit de carnali. Similiter omnes rationes inductae ad impugnandum ea quae sunt fidei, derisibiles sunt, quia non sunt secundum intentionem sacrae Scripturae» (Super Io., 3, lect. 1, \$437; cf. S. Th. I, 68, 3, in c.).

77 "Analogia vero est, cum veritas unius Scripturae ostenditur veritati alterius non repugnare» (S. Th. I, 1, 10, ad 2; Margarido, 1978; Tábet, 1986: 184-186). Cf. Augustinus, De utilitate credendi, 3, 5, PL 42, 68.

${ }^{78}$ Existen varios trabajos que se han ocupado sobre la relación entre Juan y los sinópticos en la exégesis de santo Tomás (Sales, 1925: 751-758; Cipriani, 1976: 50-52; Cirillo, 1988: 18-21). 
el autor quiere dar y no el más inmediato y superficial ${ }^{79}$. Para ello, resulta imprescindible tener en cuenta cuál es la intención de la Escritura en cada caso (Super Io., 3, lect. 1, \$437).

El interés prevalente de santo Tomás versa sobre el contenido del texto. Con todo, no deja de dar importancia a la forma en que está expresado. Habla de un modus loquendi característico de los diferentes libros de la Escritura (Hic est liber, 2). Se trata de lo que hoy solemos llamar "géneros literarios". En la Escritura existen diferentes maneras de hablar, a saber, el modo narrativo, propio de los libros históricos; el admonitorio, exhortativo y preceptivo, propio de la ley, los profetas y los sapienciales; el disputativo, propio de Job y de san Pablo; el deprecativo o laudativo, propio de los Salmos (Super Psal., Pr.). De esta suerte, puede decir que es propio de los profetas usar imágenes y figuras (In Jeremiam, Pr.; cf. In Threnos, Pr.), que la doctrina de san Pablo está expuesta de modo epistolar (Super Rom., Pr.), que es propio de los sapienciales hablar en proverbios y en qué consiste esto (Super Io., 10, lect. 2, \$1379), etc.

Estas indicaciones están orientadas a que el exégeta dé con aquello que el autor pretendía expresar al escribir. Como hemos dicho ya, se produce una coincidencia exacta entre el sentido literal y el sentido intentado por los autores (Super Rom., 4, lect. 1). El sentido literal no puede encontrarse sin tener en cuenta el contexto y las circunstancias en que fue escrito (De potentia, q. 4, a. 1, in c.; Roszak, 2013: 522-523). Por eso, se podría mencionar, por ejemplo, la condescendencia de la que usaba Moisés al escribir en el Pentateuco, cuando seguía expresiones amoldadas a la debilidad de comprensión de los israelitas ${ }^{80}$.

Encontramos un cierto intento de reconstruir la situación histórica y geográfica de los acontecimientos narrados en la Escritura. No en vano la lectura literal también es llamada "histórica". Sin embargo, las noticias históricas de la época eran bien limitadas, pero ello no impidió que el Aquinate acertase en muchos puntos ${ }^{81}$.

${ }^{79}$ Cuando algo es patente a la razón no hay por qué obligar a la Escritura a decirlo, sino que es menester explicar por qué usa esas palabras: «Haec expositio in hoc videtur deficere, quod asserit quaedam per Scripturam sacram intelligi, quorum contraria satis evidentibus rationibus probantur» (De potentia, q. 4, a. 1, ad 5). De lo contrario, corremos el riesgo de que los infieles puedan burlarse de la Escritura misma: cf. $S$. Th. I, 68, 1, in c.

${ }^{80}$ «Considerandum est quod Moyses rudi populo loquebatur, quorum imbecillitati condescendens, illa solum eis proposuit, quae manifeste sensui apparent» (S. Th. I, 68, 3 in c.; cf. S. Th. I, 67, 4, in c.; I-II, 98, 3, ad 2; Super Io., 1, lect. 2, \$84).

${ }^{81}$ Advertimos errores geográficos, por ejemplo, cuando santo Tomás identifica Sicar con Siquem (Super Io., 4, lect. 1, \$560) y Arimatea con Ramthá (ibíd., 20, lect, 6, \$2564) o cuando atribuye el nombre de Calvario a un osario de decapitados (ibíd., 19, lect. 3, \$2416). Sin embargo, conoce bien el conflicto entre judíos y samaritanos (Super Io., 4, lect. 1, \$573), la identificación del mar de Galilea con el lago de Tiberíades (ibíd., 6, lect. 1, \$839), las fiestas judías y la historia del Templo (ibíd., 7 , lect. 1, \$1013; 10, lect. 5, \$1435), la localización del pórtico de Salomón (ibíd., \$\$1436-1437), el modo de enterramiento judío (ibíd., 11, lect. $6, \$ 1543$ ), la condición vitalicia del sumo sacerdocio (ibíd., lect. 7, \$1574), la localización del torrente Cedrón (ibíd., 18, lect. 1, \$2274)... 
A pesar de su ignorancia de las lenguas bíblicas, santo Tomás posee un conocimiento amplio de la Escritura en su conjunto y es capaz de hacer valoraciones muy precisas sobre el estilo y los hebraísmos contenidos en ella. Por ejemplo, en el Comentario de san Juan hace la exégesis de la expresión lux vera (Jn 1,9) fundándose en que el término "verdadero" dentro de la Escritura se opone a "falso", tomado tanto figurada como participativamente. Esta exégesis ha sido calificada de «mucho mejor que la del Crisóstomo y de Agustín» (Spicq, 1946: 731).

Es característica de Tomás la expresión "est consuetudo Scripturae", para introducir un uso generalizado de la estilística bíblica o hebraica, o presentar una costumbre de la época en que transcurren los acontecimientos narrados (Super Io., 7, lect. 1, $\$ 1015$; Super Mt., 1, lect. 3 y 5; Super Rom., 3, lect. 2). Sabe además que en hebreo se expresan las cualidades de un individuo haciéndolas preceder del término "hijo" 82 o la forma de enfatizar las acciones por la repetición del verbo ${ }^{83}$.

Sabe de figuras retóricas que pueden ayudar a expresar la verdad revelada de manera figurada, las cuales no deben ser entendidas en sentido recto ${ }^{84}$ : así, señala metáforas (Super Io., 4, lect. 4, \$647; 16, lect. 7, \$2161), metonimias (Super Is., 35), hipérboles (Super Is., 55), etc. Ahora bien, no siempre que encuentra una afirmación aparentemente exagerada la reduce a una figura, puesto que también puede ser efecto de la sobreabundancia de la inefable verdad contenida en la Escritura ${ }^{85}$.

En ciertas ocasiones, santo Tomás dedica espacio a explicar la mística de los números, sobre todo en el Comentario a los Salmos. No obstante, es de señalar que, si bien san Agustín consagra buena parte de su Comentario al evangelio

${ }^{82}$ «Proprietas enim hebraici sermonis est ut quilibet illius rei dicatur esse filius in quo abundat, sicut dicitur 1 Reg. 26: "vivit Dominus, quod filii mortis estis". Et in hoc designatur bonitas terrae, quae fuit judaeis data” (Super Is., 5, lect. 1).

${ }_{83}$ «Dicit autem expectatio expectat, ut talis geminatio intensionem expectationis designet, secundum illud Ps. 39,1: “expectans expectavi Dominum”" (Super Rom., 8, lect. 3).

${ }^{84}$ "Secundum Augustinum, sacra Scriptura utitur quibusdam figuratis locutionibus, sicut: "Vidi Dominum sedentem super solium excelsum et elevatum", et tamen non sunt falsae: ita quando in sacra Scriptura est aliqua locutio hyperbolica. Non enim est intentio dicentis ut credatur quod dicit, sed quod intendit significare [...]. Hoc tamen non fit quando aliquid quod erat obscurum vel dubium exponitur, sed quando id quod est apertum augetur vel attenuatur» (Super Io., 21, lect. 6, \$2659).

${ }^{85}$ «Poenae effectum in internecione majorum: conturbati sunt montes, idest majores prae timore. Glossa dicit quod loquitur hyperbolice. Sed contra. Ergo excessit veritatem propheta. Et dicendum quod in aliquibus scripturis sumitur hyperbolice pro excessu veritatis simpliciter, in sacra Scriptura pro excessu veritatis secundum opinionem hominum; quasi dicat: conturbatio erit ultra quam credi possit. Vel aliter, hyperbole est quidam tropus, et in tropicis locutionibus aliud dicitur, et aliud intelligitur. unde non est falsitas quantum ad sensum quem intendit facere, sicut etiam in metaphora; quasi dicat: ita magna erit conturbatio, quod montes, si esset possibile, conturbabuntur. Psalm. 45: "conturbati sunt montes" etc.» (Super Is., 5, lect. 3). 
según san Juan a expresar los misterios contenidos en los números, santo Tomás es mucho más comedido en este punto ${ }^{86}$.

Otro elemento hermenéutico fundamental son los padres de la Iglesia, quienes gozan de un puesto aventajado para la comprensión de la Escritura (Tábet, 1986: 188; Tábet, 1979: 218-220). Algunos de ellos tuvieron el privilegio de hallarse más cerca de la primera venida de Cristo y esto les proporcionó una mayor penetración de los misterios de la fe (S. Th. II-II, 1, 7, ad 4). A ello se añade la asistencia del Espíritu Santo, que socorre a los varones espirituales para abrir el sentido de las Escrituras (Super I Cor., 2, lect. 3). El mismo Espíritu que inspiró las palabras sagradas también es quien asiste a los santos en sus obras. Por eso, la Escritura debe entenderse tal como la cumplieron Cristo y los santos en sus vidas (Super Io., 18, lect. 4, \$2321; Super Rom., 12, lect. 3).

Ahora bien, a pesar de los esfuerzos intelectuales que el exégeta haga, por mucho que busque encontrar la mejor interpretación para los textos, no por eso debe suponer que su lectura es necesariamente la mejor, pues la Escritura puede explicarse de distintas maneras (Quodlibet IV, q. 2, a. 2, in c.; S. Th. I, 68, 1, in c.). Por eso, Tomás mismo no propone sus posiciones sin precaución, a menos que las opiniones opuestas afecten a algo nuclear de la fe (S. Th. I, 74, 2, in c.). Ésta es una forma práctica de aplicación del principio de múltiple interpretación del sentido literal que hemos visto ya.

Las interpretaciones espirituales vienen a completar la interpretación literal o a valerse de la Escritura para obtener una enseñanza moral o dogmática. No obstante, no pasan de ser meras conjeturas (Quodlibet VII, q. 6, q. 1, ad 4) y tan sólo la Iglesia posee potestad para autorizarlas $(S$. Th. II-II, 1,10 , ad 1$)$. Por eso no es imprescindible extraer sentidos espirituales de todos los textos de la Escritura; al contrario, hay textos que hablan de ciertas cosas -como la Iglesia militante o la gloria- que no se pueden apropiar a otras realidades. Sin embargo, es propio del Antiguo Testamento referirse a las realidades futuras de la Nueva Alianza a través de figuras que sí se deben interpretar de modo tropológico (Quodlibet VII, q. 6, a. 2, ad 5).

\section{CONCLUSIONES}

Santo Tomás de Aquino se revela un exégeta de quien puede aprender hermosas lecciones el estudioso contemporáneo. Comenta la Escritura como teólogo que

${ }^{86}$ Cf. Augustinus, In Io., 7, 10, PL 35, 1442; 9, 6, PL 35, 1461; 9, 7, PL 35, 1461; 10, 12 , PL 35, 1473-1474; 15, 9, PL 35, 1513; 15, 21, PL 35, 1517-1518... Cf. Thomas Aquinatis, Super Io., 2, lect. 3, \$411; 5, lect. $1, \$ 711 ; 6$, lect. 2, \$880... (cf. ibíd., 21, lect. 2, \$2605). Nótese que estas pocas interpretaciones místicas están tomadas de Agustín. 
halla toda verdad revelada en el texto sagrado. Ahora bien, él mismo entiende que el teólogo ha de ponerse ante ella reconociéndola como una manifestación de la verdad increada, es decir, ansiando penetrar en el conocimiento del Verbo de Dios. Este mismo deseo de conocimiento íntimo de Dios lleva al Aquinate a la exégesis con el objeto de recoger la doctrina contenida en la Escritura y sistematizarla. Su ingenio racional, buscando la verdad divina, hizo desarrollarse en él una aguda intuición exegética, sabiendo educir de la letra de la Escritura toda su virtualidad teológica.

Recorre un camino que se desliza desde la superficie de la letra hasta su significado profundo. Así es posible penetrar en las realidades a las que se refiere la Escritura, las cuales están de suyo relacionadas con otras. Esta relación indica un significado interno que nos permite acceder a la revelación divina, llevada a cabo no sólo con palabras sino, primero de todo, con una intervención divina en la historia.

En la Lectura super Ioannem se aprecian todas las características de la exégesis de Tomás de manera sobresaliente. En ella descubrimos ejemplos esclarecidos de minuciosidad exegética empleados para desentrañar los acontecimientos históricos y así penetrar profundamente en el significado espiritual que contienen. La materialidad del texto, no menos que los acontecimientos históricos, forman parte esencial del itinerario conducente a reconocer las enseñanzas más sublimes sobre Dios.

En su tiempo, la exégesis principalmente literal del Aquinate significó un acercamiento a la escuela de Hugo de san Víctor y una continuidad con san Alberto. No obstante, tampoco rechazó del todo el sentido espiritual, pues ayudaba a sumergirse en el hontanar de la revelación de Dios, autor principal de la Escritura. Ahora bien, creía que la exégesis espiritual debía huir de toda arbitrariedad. De este modo lograba la continuidad con la tradición, tratando de buscar, a partir de un ahondamiento espiritual de los textos, el designio divino oculto en las palabras reveladas. Por otra parte, al poner límites al método de la exégesis espiritual, conseguía conducir el deseo de conocer a Dios por los caminos que Él mismo había escogido para darse a conocer.

RECIBIDO: agosto 2019; ACEPTADO: octubre 2019.

\section{REFERENCIAS BIBLIOGRÁFICAS}

ARANDA, G. (1977): "Acerca de la verdad contenida en la Sagrada Escritura (Una "quaestio" de Santo Tomás citada por la Const. "Dei Verbum”)", Scripta Theologica 9: 393-426.

Benort, P. (1978): «Saint Thomas et l'Inspiration des Écritures», en Tommaso d'Aquino nel suo settimo centenario. Atti del congresso internazionale, vol. 3, Edizioni Domenicane Italiane, Roma/ Napoli, pp. 19-30.

BoninO, S.-T. (2004): «La théologie de la vérité dans la Lectura super Ioannem de saint Thomas d'Aquin", Revue Thomiste 104: 141-166.

BoninO, S.-T. (2005): «The Role of the Apostles in the Communication of Revelation according to the Lectura super Ioannem of St. Thomas Aquinas», en DAUPHINAIS, M. and LeVERING, M. (eds.), Reading John with St. Thomas Aquinas: theological exegesis and speculative theology, The Catholic University of America Press, Washington, D. C., pp. 318-346. 
Boyle, J. F. (2005): «Autorial Intention and the Divisio textus», en DAupHINAIS, M. and LeVering, M. (eds.), Reading John with St. Thomas Aquinas: theological exegesis and speculative theology, The Catholic University of America Press, Washington, D. C., pp. 3-8.

CAI, R. (ed.) (19525): S. Thomas Aquinatis. Super Evangelium S. Ioannis Lectura, Marietti, Romae.

Casanova, C. A. et al. (ed.) (2014): Santo Tomás de Aquino. Comentario al libro de los salmos, 1 a 15, Santiago de Chile, RIL.

Casanova, C. A. et al. (ed.) (2016): Santo Tomás de Aquino. Comentario al libro de los salmos, 16 a 27, Santiago de Chile, RIL.

Casanova, C. A. et al. (ed.) (2018): Santo Tomás de Aquino. Comentario al libro de los salmos, 28 a 40, Santiago de Chile, RIL.

Casciaro, J. M. (1974): «Santo Tomás ante sus fuentes», Scripta Theologica 6: 11-65.

Centi, T. S. (1990): «Introduzione», en Tommaso d'Aquino, Commento al Vangelo di San Giovanni, vol. 1, Città Nuova, Roma.

Ceuppens, F. (1930): «Quid S. Thomas de multiplici sensu litterali in S. Scriptura senserit?», Divus Thomas 7: 164-175.

Chenu, M.-D. (1924): Introduction à l'étude de Saint Thomas d'Aquin, Université de Montréal, Publications de l'Institut d'Études Médievales, Montréal.

Chenu, M.-D. (1962): Santo Tomás de Aquino y la teología, Aguilar, Madrid.

CIPRIANI, S. (1976): «Riflessioni Esegetiche su "Super S. Joannis Evangelium Lectura” di S. Tommaso», en Tommaso d'Aquino nel suo settimo centenario. Atti del congresso internazionale, vol. 4, Edizioni Domenicane Italiane, Roma-Napoli, pp. 41-59.

Cirillo, A. (1988): Cristo Rivelatore del Padre nel vangelo di S. Giovanni secondo commento di S. Tommaso d'Aquino, Pontificia Studiorum Universitas a S. Thoma Aq. in Urbe, Romae.

Conticello, C. G. (1990): «San Tommaso ed i padri: la Catena Aurea super Ioannem», Archives d'Histoire Doctrinale et Littéraire du Moyen Âge 65: 31-92.

Dauphinais, M. (2005): “And They Shall All Be Taught by God”. Wisdom and the Eucharist in John 6", en Dauphinais, M. and Levering, M. (eds.), Reading John with St. Thomas Aquinas: theological exegesis and speculative theology, The Catholic University of America Press, Washington, D. C., pp. 312-317.

Dauphinais, M. and Levering, M. (eds.) (2005): Reading John with St. Thomas Aquinas: theological exegesis and speculative theology, The Catholic University of America Press, Washington, D. C.

Dauphinais, M. and Levering, M. (eds.) (2012): Reading Romans with St. Thomas Aquinas, The Catholic University of America Press, Washington, D. C.

De Miguel y Sicilia, J. J. (1975): «Los Padres de la Iglesia en la criteriología teológica de santo Tomás de Aquino", Scripta Theologica 7: 125-161.

De Miguel y Sicilia, J. J. (1979): «La autoridad de los Padres de la Iglesia en Santo Tomás de Aquino», Theologica 14: 165-191.

Di MArCO, A. (1978): «S. Tommaso e la pluralità dei sensi biblici nella problematica odierna», en Tommaso d'Aquino nel suo settimo centenario. Atti del congresso internazionale, vol. 4, Edizioni Domenicane Italiane, Roma/Napoli, pp. 60-69.

EmERY, G. (2005): «Biblical Exegesis and the Speculative Doctrine of the Trinity in St. Thomas Aquinas's Commentary on St. John", en Dauphinais, M. and Levering, M. (eds.), Reading John with St. Thomas Aquinas: theological exegesis and speculative theology, The Catholic University of America Press, Washington, D. C., pp. 23-61. 
FernándeZ, C. (1909): «Sistema exegético de Santo Tomás de Aquino», España y América 1: abril 311; mayo 230-236; junio 414-427; septiembre 385-396; octubre 119-130.

FERnÁNdeZ, C. (1910): «Sistema exegético de Santo Tomás de Aquino», España y América 2: enero 122-131.

Freund, R. (2014): «The Two Bethsaidas», en Ellens, J. H. (ed.), Bethsaida in Archaelogy, History and Ancient Culture, Cambridge Scholars Publishing, Newcastle upon Tyne, pp. 26-46.

GARDEIL, A. (1903): «La réforme de la Théologie Catholique, Les procédés exégétiques de saint Thomas», Revue Thomiste 11: 428-457.

Geenen, J. G. (1946): «Saint Thomas et les Pères», en Amann, É. (ed.), Dictionnaire de Théologie Catholique, vol. 15, Letouzey et Ané, Paris, pp. 738-761.

GeEnen, J. G. (1975): «Le fonti patristiche come "autorità" nella teologia di S. Tommaso», Sacra Doctrina 20: 55-67.

Mailhiot, M.-D. (1959): «La pensée de saint Thomas sur le sens spirituel», Revue Thomiste 59: 613-663.

Mandonnet, P. (1909): «Des écrits authentiques de Saint Thomas d'Aquin», Revue Thomiste 17: 38-55, 155-181, 257-274, 441-455, 562-573, 678-691.

Mandonnet, P. (1910): «Des écrits authentiques de Saint Thomas d'Aquin», Revue Thomiste 18: 62-82, 289-307.

Mandonnet, P. (1928): «Chronologie des Écrits Scripturaires de saint Thomas d'Aquin», Revue Thomiste 11: 27-45, 116-155, 211-245.

Mandonnet, P. (1929): «Chronologie des Écrits Scripturaires de saint Thomas d'Aquin», Revue Thomiste, 12: 53-69, 132-145, 489-519.

Manresa LamarCA, I. M. (2017): «The literal sense and the spiritual understanding of Scripture according to St. Thomas Aquinas», Biblica et Patristica Thoruniensia 10: 341-373.

Manresa Lamarca, I. M. (2018): La exégesis en el espíritu según santo Tomás de Aquino, Instituto Teológico San Idelfonso, Toledo.

Margarido, J. (1978): «A analogia da Fé na exegese de S. Tomás», Theologica 13: 309-353.

MÉnARD, E. (1964): La Tradition. Révelation, Écriture, Église selon Saint Thomas d'Aquin, Desclée de Brouwer, Paris.

Muratori, L. A. (ed.) (1727): Rerum Italicarum Scriptores, vol. 11, Societas Palatina, Mediolani.

PARENTI, S. (1975): «Il senso letterale della Scrittura secondo S. Tommaso», Sacra Doctrina 20: 69-97.

PARETSKY, A. (1994): «The influence of Thomas the Exegete on Thomas the Theologian: The Tract on Law (Ia-IIae, qq. 90-108) as a Test Case», Angelicum 71: 549-577.

Perrella, G. (1945): «Il pensiero di S. Agostino e S. Tommaso circa il numero del senso letterale nella S. Scrittura", Biblica 26: 277-302.

Persson, E. (1970): Sacra doctrina. Reason and Revelation in Aquinas, Basil Blackwell, Oxford.

PhilipPe, M.-D. (1998): «Préface», en THOMAS D’Aquin, Commentaire sur l'Évangile de saint Jean, vol. 1, Cerf, Paris, pp. 7-26.

Revuelta, J. (1971): «Los comentarios bíblicos de Santo Tomás», Scripta theologica 3: 539-579.

Rossi, M. M. (1994): «La divisio textus nei commenti scritturistici di S. Tommaso d'Aquino: un procedimento solo esegetico?», Angelicum 71: 537-548.

RoszaK, P. (2013): «Between Dialectics and Metaphor: Dynamics of the Exegetical Practice of Thomas Aquinas», Angelicum 90: 507-534. 
ROSZAK, P. (2014): «Exégesis y metafísica. En torno a la hermenéutica bíblica de Tomás de Aquino», Salmanticensis 61: 301-323.

RosZAK, P. (2016): «Exegesis and Contemplation. The Literal and Spiritual Sense of Scripture in Aquinas' Biblical Commentaries», Espíritu 65: 481-504.

RoszAK, P. (2017): «Depravatio Scripturae. Tomás de Aquino ante los errores hermenéuticos en la exégesis bíblica", Scripta Theologica 49: 31-58.

RoszAK, P. (2018): «Language, Metaphysics and the Bible. The Philosophical Background of Aquinas's Exegesis of Sacred Scripture», European Journal of Science and Theology 14: 123-135.

RosZAK, P. (2019): «Principes et pratiques exégétiques dans l'Expositio super Iob de Thomas d'Aquin», Revue thomiste 119: 5-30.

RosZAK, P., Vijgen, J. (eds.) (2015): Reading Sacred Scripture with Thomas Aquinas. Hermeneutical Tools, Theological Questions and New Perspectives, Brepols, Turnhout.

RoszaK, P., Vijgen, J. (eds.) (2018): Towards a Biblical Thomism. Thomas Aquinas and the Renewal of Biblical Theology, EUNSA, Pamplona.

SALES, M. (1925): «De origine et indole quarti Evangelii iuxta doctrinam D. Thomae», Divus Thomas 2: 734-767.

Salguero, J. (1978): «Santo Tomás de Aquino y la hermenéutica bíblica», en Tommaso d’Aquino nel suo settimo centenario. Atti del congresso internazionale, vol. 4, Edizioni Domenicane Italiane, Roma/Napoli, pp. 29-40.

SANTI, F. (1994) «L'esegesi biblica di Tommaso d'Aquino nel contesto dell'esegesi biblica medievale», Angelicum 71: 509-535.

SMalley, B. (1972): Lo studio della Bibbia nel Medioevo, Il Mulino, Bologna.

SpICQ, C. (1944): Esquisse d'une Histoire de l'Exégèse latine au Moyen Âge, J. Vrin, Paris.

SPICQ, C. (1946): «Saint Thomas d'Aquin exégète», en Amann, É. (ed.), Dictionnaire de Théologie Catholique, vol. 15, Letouzey et Ané, Paris, pp. 694-738.

Synave, P. (1924): «Le Canon Scripturaire de saint Thomas d'Aquin», Revue Biblique 33: 522-533.

Synave, P. (1926): «La doctrine de Saint Thomas d'Aquin sur le sens littéral des Écritures», Revue Biblique 35: 40-65.

TÁBet, M. A. (1979): «La lectura cristiana de la Biblia según santo Tomás», Scripta Theologica 11: 197-229.

TÁBET, M. A. (1980): «El uso de las ciencias humanas en la hermenéutica bíblica, según la doctrina de santo Tomás», Euntes Docete 33: 427-455.

TÁBET, M. A. (1986): «La perspectiva sobrenatural de la hermenéutica bíblica de santo Tomás», Scripta Theologica 18: 175-196.

Torrell, J.-P. (2008): Initiation à Saint Thomas d'Aquin. Sa persone et son æeuvre, Academic Press/ Cerf, Fribourg/Paris.

Venard, O.-T. (2003): «Croire en savant. Saint Thomas Bibliste», en: BoninO, S.-Th. et al., Thomistes, ou de l'actualité de saint Thomas d'Aquin, Parole et Silence, Toulouse, pp. 37-47.

Vosté, I.-M. (1937): «De investigandis fontibus patristicis Sancti Thomae», Angelicum 14: 417-434.

WeISHEIPL, J. A. (1980): «An Introduction to the Commentary on the Gospel of Saint John of St. Thomas Aquinas", en S. ThOMAS AquinaS, Commentary on the Gospel of St. John, vol. 1, Magi Books, Albany, pp. 1-19. 
WeisheIPl, J. A. (1994): Tomás de Aquino. Vida, obras y doctrina, EUNSA, Pamplona.

ZARB, S.-M. (1930): «Utrum S. Thomas unitatem an vero pluralitatem sensus litteralis in Sacra Scriptura docuerit?», Divus Thomas 7: 235-359.

ZARB, S.-M. (1932): «Unité ou multiplicité de sens littéraux dans la Bible», Revue Thomiste 15: 270-279. 